\title{
The New Era of the Lymphatic System: No Longer Secondary to the Blood Vascular System
}

\author{
Inho Choi, Sunju Lee, and Young-Kwon Hong \\ Department of Surgery, Department of Biochemistry and Molecular Biology, Norris Comprehensive \\ Cancer Center, Keck School of Medicine, University of Southern California, Los Angeles, California 90033 \\ Correspondence: young.hong@usc.edu
}

The blood and lymphatic systems are the two major circulatory systems in our body. Although the blood system has been studied extensively, the lymphatic system has received much less scientific and medical attention because of its elusive morphology and mysterious pathophysiology. However, a series of landmark discoveries made in the past decade has begun to change the previous misconception of the lymphatic system to be secondary to the more essential blood vascular system. In this article, we review the current understanding of the development and pathology of the lymphatic system. We hope to convince readers that the lymphatic system is no less essential than the blood circulatory system for human health and well-being.

$\mathrm{T}_{\mathrm{s}}^{\mathrm{h}}$ he human body has two major circulatory systems: the blood and lymphatic systems. Although both systems were initially described by Hippocrates and share so many functional, structural, and anatomical similarities, the two vascular systems have had very different fates in science and medicine: Although the blood vascular system has been intensively and extensively studied for a long time, the lymphatic system, in contrast, has been considered less important, invisible, secondary to the blood vascular system, and thus largely neglected by scientists and clinicians until recent years. However, a series of landmark discoveries in past decades has unraveled much of the mystery of the lymphatic system and yielded a burst of new knowledge in the field of vascular biology and medicine. Modern molecular, cellular, and genetic approaches as well as the state-of- the-art imaging technologies have allowed true appreciation of the value of the lymphatic system as the other vascular system, no longer secondary to the blood vascular system. In this review, we discuss the current understanding of the development and function of the lymphatic system and human diseases related to the lymphatic system.

\section{STRUCTURE AND FUNCTION OF THE LYMPHATIC SYSTEM}

The lymphatic system is a linear network of lymphatic vessels and secondary lymphoid organs. Macroscopically, the blood vascular system is literally a circular system in which the fluid (blood) leaves the heart; runs through the arteries, arterioles, capillary plexus, venules, and veins; and returns to the heart (Fig. 1A)

Editors: Michael Klagsbrun and Patricia D'Amore

Additional Perspectives on Angiogenesis available at www.perspectivesinmedicine.org

Copyright (C) 2012 Cold Spring Harbor Laboratory Press; all rights reserved; doi: 10.1101/cshperspect.a006445

Cite this article as Cold Spring Harb Perspect Med 2012;2:a006445 
I. Choi et al.

(Alitalo 2002; Alitalo and Carmeliet 2002; Karkkainen et al. 2002). In contrast, the lymphatic system is a blunt-ended linear system, in which tissue fluids, cells, and large extracellular molecules, collectively called lymph, are drained into the initial lymphatic capillary vessels that begin at the interstitial spaces of tissues and organs; are transported to thicker collecting lymphatics, which are embedded with multiple lymph nodes; and are eventually returned to the blood circulation through the thoracic or lymphatic ducts that join to the subclavian veins. Microscopically, whereas blood capillaries are lined by the innermost blood vascular endothelial cells (BECs), which are covered by the basement membranes and then surrounded by smooth muscle-like pericytes, lymphatic capillaries are lined with a single layer of partly overlapping lymphatic endothelial cells (LECs) without being surrounded by the basement membrane or pericytes (Tammela and Alitalo 2010). Whereas cross sections of blood capillaries are
A

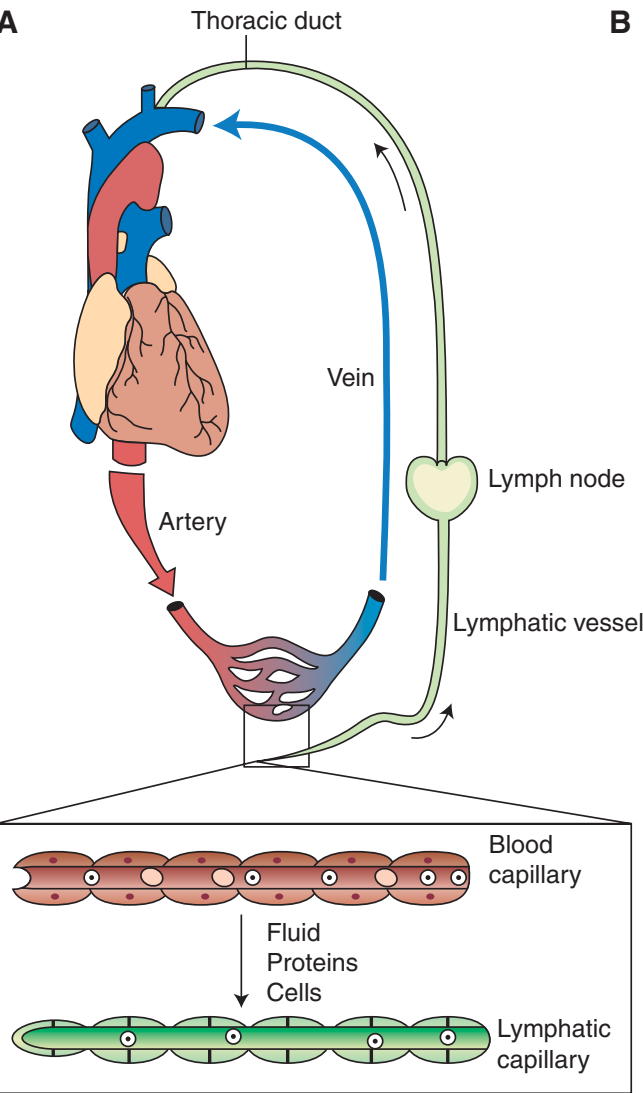

B

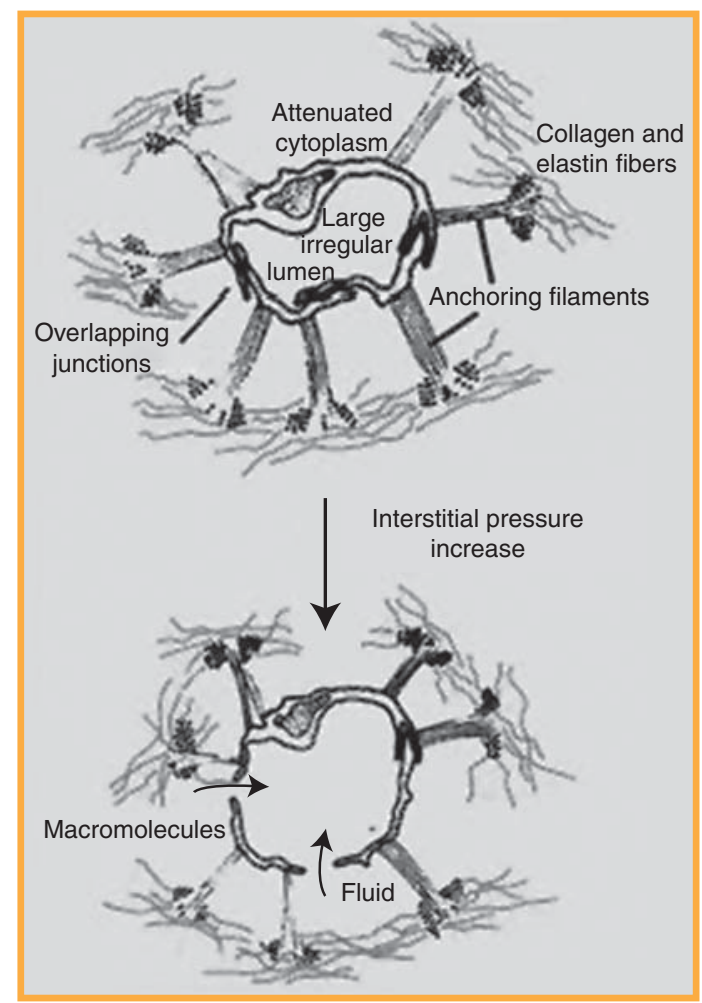

Figure 1. Macroscopic view of the blood versus lymphatic system and illustration of the structures of lymphatic capillaries. (A) The blood vascular system is a circular and closed system in which the fluid (blood) leaves from and returns to the same organ (heart). In comparison, the lymphatic system is a linear system in which the lymphatic capillaries at the peripheral tissues drain the fluid (lymph) containing cells, proteins, and macromolecules and transport it back to the blood vascular system through the lymphatic-blood junction at the end of the thoracic duct. (Diagram modified from Karkkainen et al. 2002.) (B) Microstructure of lymphatic capillaries in the skin. Lymphatic capillaries are irregular shaped and stay collapsed. When the interstitial fluid pressure increases because of fluid accumulation, the anchoring filament bundles pull lymphatic endothelial cells and open up the cell-cell junctions so that the lymph fluids can enter the lumen of lymphatic vessels for transport. (Illustration modified from Skobe and Detmar 2000.) 
Lymphatics, the Other Circulatory System

round and homogeneously shaped owing to hemodynamic pressure, lymphatic capillaries are irregularly shaped and usually stay collapsed (Alitalo 2002; Alitalo and Carmeliet 2002; Karkkainen et al. 2002). Lymphatic vessels can be found in all of the vascularized organs and tissues except retina, bone, and brain. (See Table 1 for the summarized comparison between BECs and LECs.)

Importantly, capillary LECs are attached by filament bundles and then directly anchored to the extracellular matrices (Leak and Burke 1966, 1968). When interstitial pressure increases, the anchoring filaments are operated to pull the cells and open up the overlapping junctions (or flaps), which allows the lymph fluids to drain into lymphatic capillaries for recirculation (Fig. 1B) (Leak and Burke 1966, 1968). Therefore, these overlapping junctions of capillary LECs mechanically function as primary valves that unidirectionally control lymph fluid drainage and are laced with discontinuous, specialized button-like intercellular adhesion points with proteins found in tight and adherens junctions (Baluk et al. 2007). In comparison, LECs of the collecting lymphatic vessels, opted for fluid transport rather than drainage, are now seamlessly aligned with each other by more tight, zipper-like junctions and ensheathed with the basement membranes

Table 1. Comparison of blood vascular endothelial cells (BECs) and lymphatic endothelial cells (LECs)

\begin{tabular}{|c|c|c|}
\hline Feature & Blood vessels/BEC & Lymphatics/LEC \\
\hline Constituents & Blood, blood cells & $\begin{array}{l}\text { Lymph (interstitial fluid rich in protein, fat, } \\
\text { and lipids, extravasated immune cells, and } \\
\text { large extracellular molecules) }\end{array}$ \\
\hline Gross structure & Closed, circular & Open, linear \\
\hline Start/end & Heart/heart & $\begin{array}{l}\text { Tissue/lymph-vein connection of the } \\
\text { thoracic duct }\end{array}$ \\
\hline $\begin{array}{l}\text { Hierarchical } \\
\text { division }\end{array}$ & $\begin{array}{l}\text { Arteries, arterioles, capillaries, venules, } \\
\text { veins }\end{array}$ & $\begin{array}{l}\text { Capillaries, precollectors, collecting vessels, } \\
\text { thoracic duct, lymph nodes }\end{array}$ \\
\hline Vessel wall & $\begin{array}{l}\text { Adherens and tight junctions, } \\
\text { continuous basement membrane, } \\
\text { pericytes, or vascular smooth muscle } \\
\text { cells }\end{array}$ & $\begin{array}{l}\text { Overlapping LECs, no tight junctions, } \\
\text { anchoring filaments, discontinuous } \\
\text { basement membrane, few pericytes } \\
\text { (collecting lymphatic vessels have both } \\
\text { continuous membranes and mural cells) }\end{array}$ \\
\hline Development & Vasculogenesis and angiogenesis & $\begin{array}{l}\text { Lymphangiogenesis (budding from cardinal } \\
\text { vein) }\end{array}$ \\
\hline Origin & $\begin{array}{l}\text { Mesoderm, endothelial stem/precursor } \\
\text { cells from bone marrow for adults }\end{array}$ & $\begin{array}{l}\text { Mesoderm (vein) during development, } \\
\text { lymphatic progenitor cells from bone } \\
\text { marrow for adults }\end{array}$ \\
\hline $\begin{array}{l}\text { Examples of cell } \\
\text { type-specific } \\
\text { markers }\end{array}$ & CD34, CD105/endoglin & Prox1, LYVE-1, VEGFR-3, and podoplanin \\
\hline Absence & Cartilage, cornea & $\begin{array}{l}\text { Cartilage, brain, bone, spinal cord, and the } \\
\text { retina }\end{array}$ \\
\hline Functions & $\begin{array}{l}\text { Hemostasis, inflammation, leukocyte } \\
\text { trafficking, barrier function, delivery } \\
\text { for oxygen, nutrients, and tissue wastes }\end{array}$ & $\begin{array}{l}\text { Tissue fluid homeostasis, absorption of large } \\
\text { molecules and lipids in the digestive } \\
\text { systems, trafficking of lymphocytes and } \\
\text { antigen-presenting cells to regional lymph } \\
\text { nodes, transport of degraded extracellular } \\
\text { molecules, cell debris, and lymph fluid }\end{array}$ \\
\hline Heterogeneity & $\begin{array}{l}\text { Well-established phenotypic } \\
\text { heterogeneity }\end{array}$ & $\begin{array}{l}\text { Comparable LEC heterogeneity was reported. } \\
\text { LEC fate is highly plastic in response to } \\
\text { genetic and environmental stimuli }\end{array}$ \\
\hline
\end{tabular}


and pericytes/smooth muscle cells that propel drained lymph fluids back to recirculation (Baluk et al. 2007). Like the veins, collecting lymphatic vessels and ducts are equipped with bileaflet secondary valves to prevent retrograde flow of the lymph, and optimal lymph flow is effectively controlled by multiple factors including lymphatic muscle contractions (Dougherty et al. 2008; Muthuchamy and Zawieja 2008).

In addition to the tissue fluid homeostasis, the lymphatic system serves as a conduit for trafficking of lymphocytes and antigenpresenting cells to regional lymph nodes, where the immune system encounters pathogens, microbes, and other immune elicitors. Lymphnode lymphatic vessels, which uptake various antigens from peripheral tissues, are positively regulated by chemokines/cytokines secreted by $\mathrm{B}$ cells, macrophages, and dendritic cells during inflammation (Jeon et al. 2008; Kataru et al. 2009; Kim et al. 2009). Toll-like receptor (TLR)-4 is highly expressed in LECs and contributes to lipopolysaccharide (LPS)-induced lymphangiogenesis by chemotactic recruitment of macrophages (Kang et al. 2009). Notably, a recent study showed that lymph nodes in athymic nude mice have excessive lymphatic vessels and that interferon- $\gamma$ released by T lymphocytes negatively regulates lymph-node lymphatic vessel formation by suppressing key lymphatic molecules (Kataru et al. 2011). Importantly, lymphatic vessels can perform functions beyond passive conduits for immune response. Inflamed LECs can directly modulate inflammatory response by suppressing dendritic cell maturation and function through an Mac-1/ ICAM-1-dependent mechanism (Podgrabinska et al. 2009). Inhibition of lymphatic-specific vascular endothelial growth factor receptor (VEGFR)-3 increased inflammatory edema formation and inflammatory cell accumulation along with inhibition of lymphangiogenesis in the inflammatory skin (Huggenberger et al. 2010) and arthritis (Guo et al. 2009), and, conversely, activation of lymphangiogenesis by genetic delivery of the lymphangiogenic factor VEGF-C suppressed chronic skin inflammation, suggesting that induction of functional lymphangiogenesis could be a novel strategy to treat chronic inflammatory disorders (Huggenberger et al. 2010, 2011). Moreover, LECs modulate inflammatory response by secreting CCL21, a chemokine for recruitment of the CCR7-positive dendritic cells to lymphatic vessels (Saeki et al. 1999; Randolph 2001; Wiley et al. 2001; Vigl et al. 2011). These studies indicate that lymphatic vessels are not mere passive conduits for immune cells but actively participate in modulating the immune responses. Interestingly, while lymphatic vessels transport lymph fluids, both interstitial pressure and fluid flow can also activate LECs, thus increasing fluid/solute permeability and uptake (Swartz et al. 2008; Miteva et al. 2010), and regulate lymphatic morphogenesis in vitro and in vivo (Boardman and Swartz 2003; Goldman et al. 2007; Helm et al. 2007; Lund and Swartz 2010).

Moreover, lymphatic vessels such as lacteals in the intestines absorb and transport large molecules, fats, and lipids in the digestive system mainly in the form of lipoprotein such as chylomicrons - large lipoprotein particles that are created by the enterocytes of the intestine and consist of triglycerides, phospholipids, cholesterol, and proteins. Notably, lymph fluid and chylomicrons can stimulate adipocyte differentiation (Nougues et al. 1993; Rosen 2002). This finding is consistent with the fact that chronic lymphedema is often associated with tissue fibrosis and accumulation of fat and adipose tissues (Rockson 2000, 2009). A mouse genetic study showed that when lymphatic vessel integrity is compromised, the lymph fluids rich in fat and lipids leaked out from mispatterned or ruptured lymphatic vessels and activated fat accumulation, leading to adult-onset obesity (Harvey et al. 2005).

Unfortunately, many malignant tumors take advantages of the lymphatic system for their dissemination. A large number of in vitro animal and human studies have shown a causal relationship between lymphatic vessel density and tumor metastasis (Skobe et al. 2001; Stacker et al. 2001; Das and Skobe 2008), and more scientific and clinical attention is needed to prevent and intervene tumor metastasis through lymphatic vessels. 
Lymphatics, the Other Circulatory System

\section{DEVELOPMENT OF THE LYMPHATIC SYSTEM}

\section{Phylogenetic Standpoints}

From the phylogenetic standpoint, the lymphatic system is believed to have first appeared in vertebrates (Rusznyak et al. 1967). Zebrafish has served as a great experimental tool for vascular research and was thought to lack lymphatic circulation for a long time. However, a primitive lymphatic system with evolutionarily conserved structural and cellular features was recently discovered in zebrafish (Yaniv et al. 2006) and has been enormously valuable in various genetic studies. Amphibians, reptiles, and flightless birds have also developed a lymphatic system with a specialized lymph heart that drives lymph drainage and transport. The lymphatic system further evolved in flying birds and mammals to lose the lymph heart and instead acquire lymph nodes for the immune functions.

\section{Historical Perspectives}

Hippocrates (460-377 B.c.) first described the lymphatic vessel as "white blood" and coined the term "chyle" (from the Greek chylos, meaning juice) (Grotte 1979; Chikly 1997). Chyle is a milky tissue fluid consisting of emulsified fats and free fatty acids, collectively called lymph, which is formed in the digestive system and taken up by the specialized lymph vessels known as lacteals. Subsequently, the lymphatic system was further illustrated by Greek physicians Herophilus (335-280 B.c.) and Erasistratus (304250 B.C.), two founding fathers of human anatomy who are believed to have performed-for the first time-systematic dissections of human cadavers (Lord 1968; Leeds 1977; Chikly 1997). After the Hippocrates era, the lymphatic system was largely forgotten until 1627, when an Italian anatomist, Gaspare Aselli, rediscovered the lymphatic system (mesentery lymphatic vessels) as the "venae albae et lacteae (milky veins)" from a well-fed dog, while studying the diaphragm (Asellius 1627). He postulated that foods were digested and fragmented into numerous droplets and then transported via the "chyliferous" vessels (Lord 1968; Leeds 1977; Chikly 1997). Following this discovery of the mesentery lymphatics, additional anatomical structures of the lymphatic system such as the collecting lymphatic vessels and thoracic ducts were identified and characterized.

At the beginning of the 20th century, researchers proposed two competing theories on the histogenetic origin of the lymphatic system. One hypothesis argued for the blood vascular origin of lymphatics, in which the lymphatic system is derived from the blood vascular system during early development (the "centrifugal model"). In a sharp contrast, the other theory, more widely accepted then, claimed that LECs are independently differentiated from mesenchymal cell-derived lymphangioblasts and that the primitive lymphatic plexuses are formed by these lymphatic stem cells first and then gain connections to the embryonic vein only later (the "centripetal model"). In 1902, the American anatomist and medical researcher Florence Rena Sabin, based on experiments on ink injection into the veins of pig embryos, demonstrated that the lymphatic system is derived from the early embryonic vein (Sabin 1902, 1904). Although the Sabin experiments largely resolved the scholastic debate, the presence of lymphatic progenitor cells (lymphangioblasts) and their critical roles have been further validated in embryonic development of the nonmammalian lymphatic system (Wilting et al. 2001, 2003, 2006) and during postdevelopmental lymphangiogenesis in mammals including rodents and human (Kerjaschki et al. 2006; Lee et al. 2010a).

\section{Initial Steps for Lymphatic Specification and Differentiation}

Although an in-depth comparative study on blood versus lymphatic vascular systems was first initiated about half a century ago (Leak and Burke 1966), the dearth of lymphaticspecific molecular and cellular markers significantly hampered efforts. However, a series of landmark discoveries made in the late 1990s has opened a new door to lymphatic research. One of the most groundbreaking findings was the identification of the LEC-specific vascular endothelial growth factor receptor (VEGFR)-3 
I. Choi et al.

(Kaipainen et al. 1995). VEGFR-3 is a member of the VEGF receptor family and structurally related to VEGFR-1 and VEGFR-2. VEGFR-3 expression is detectable in a majority of vascular endothelial cells during early development but restricted to lymphatic plexuses at later stages of development and postdevelopment (Kaipainen et al. 1995). Thus, VEGFR-3 is the first lymphatic-specific marker and has been extensively used in the field of lymphatic research. However, genetic deletion of VEGFR-3 resulted in defective blood vessel development with abnormally organized large vessels and fluid accumulation in the pericardial cavity at mouse embryonic day 9.5 (E9.5), when the lymphatic development is about to begin (Fig. 2). Thus, the role of VEGFR-3 specifically in early lymphatic development has not been readily studied (Dumont et al. 1998). Instead, knockout studies of VEGF-C, a ligand for VEGFR-3, have provided a wealth of important information for the initial steps in early lymphatic development (Karkkainen et al. 2004). In VEGF-C-deficient mice, endothelial cells are still committed to the lymphatic lineage but unable to form rudimentary lymphatic vessels. This mutant phenotype was rescued by VEGF$C$ and VEGF-D, another VEGFR-3 ligand, but not by VEGF-A, showing VEGFR-3 specificity.
The knockout embryos lack a functional lymphatic system and die prenatally from fluid accumulation in tissues. Notably, VEGF-C heterozygote mice developed cutaneous lymphatic hypoplasia and lymphedema, indicating the essential roles of VEGF-C in normal lymphatic development (Karkkainen et al. 2004).

The controversy regarding the origin of the lymphatic system continued for a hundred years until 1998, when the first mutant mouse with failed lymphatic development supported Sabin's hypothesis of the blood vascular origin of the lymphatic system (Wigle and Oliver 1999; Wigle et al. 2002). Wigle et al. discovered that deletion of a homeodomain transcription factor, Prox1, resulted in arrest of lymphatic endothelial differentiation at an early stage and that Proxl knockout mice fail to develop a lymphatic system. Moreover, Prox1 is expressed in a subset of endothelial cells in the cardinal vein at mouse E9.5, and the Prox1-positive endothelial cells bud off and migrate out to form the rudimentary lymphatic vessels, known as jugular lymph sacs (Fig. 2). Importantly, the lymphatically differentiating, budding endothelial cells gradually up-regulate LEC-signature genes and progressively down-regulate BEC-specific genes as embryos develop (Wigle and Oliver 1999; Wigle et al. 2002). Thus,

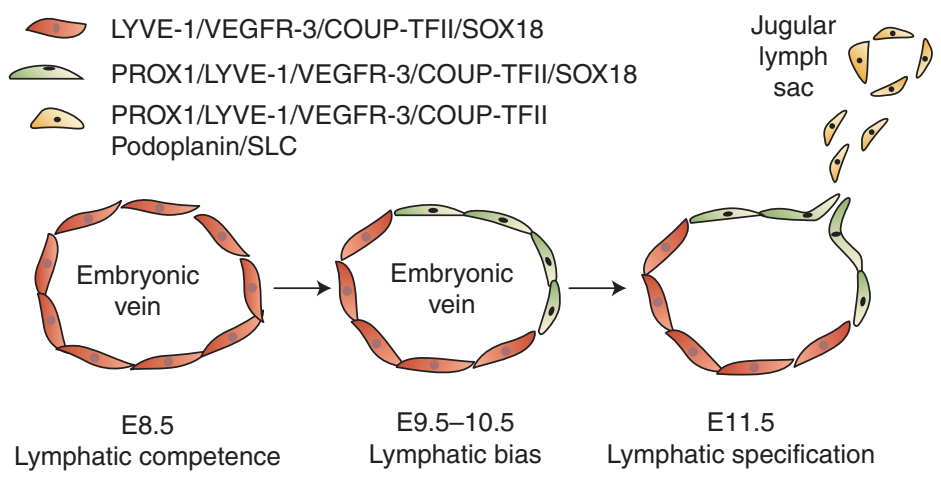

Figure 2. Current model of a stepwise embryonic development of the mammalian lymphatic system. At mouse E8.5, endothelial cells in the vein express LYVE-1, VEGFR-3, COUP-TFII, and SOX18 and are potentially capable of lymphatic differentiation ("lymphatic competence"). At E9.5-E10.5, Prox1, the master regulator for lymphatic development, is up-regulated in a subset of venous endothelial cells by an inductive signal ("lymphatic bias"). These Prox1-positive cells begin to migrate out and form the rudimentary lymphatic vessels, known as jugular lymph sacs, at E11.5, expressing additional lymphatic molecules such as podoplanin and SLC ("lymphatic specification"). (Diagram modified from Oliver and Detmar 2002.) 
Lymphatics, the Other Circulatory System

Prox1 expression is restricted in LECs, serving as an LEC signature. Furthermore, Proxl was shown to induce lymphatic reprogramming postdevelopmentally when overexpressed in BECs and to be required continuously to maintain LEC phenotypes (Wigle and Oliver 1999; Hong et al. 2002; Petrova et al. 2002; Wigle et al. 2002; Johnson et al. 2008), gaining the honorable name: "the master control gene for lymphatic development."

Following the identification of VEGFR-3 and Proxl as the LEC-signature markers, two additional LEC-specific molecules, lymphatic vessel endothelial hyaluronan receptor (LYVE)-1 and podoplanin, were simultaneously reported in 1999. LYVE-1 was originally isolated in an effort to identify a receptor for hyaluronan (HA), an extracellular matrix glycosaminoglycan that is an abundant component of skin and mesenchymal tissues and facilitates cell migration during wound healing, inflammation, and embryonic morphogenesis (Banerji et al. 1999). It turned out that LYVE-1 is selectively expressed in LECs and is a homolog of CD44, another HA receptor mainly found in blood vessels (Jackson 2009). Like VEGFR-3, LYVE-1 expression is detected in embryonic veins at an early stage of development and is later restricted in LECs (Oliver 2004). LYVE-1 expression in LECs becomes diminished as the capillary lymphatic plexus matures to collecting lymphatic vessels (Petrova et al. 2004; Makinen et al. 2005). Interestingly, both LYVE-1 single and LYVE-1/CD44 double knockout mice still develop a normal lymphatic system without any significant functional defects in tissue fluid homeostasis (Gale et al. 2007; Luong et al. 2009). Although LYVE-1 is used as an important LEC marker, it is also expressed in activated tissue macrophages and sinusoidal endothelial cells of the liver and spleen (Jackson 2003, 2004).

Podoplanin (PDPN), a mucin-type transmembrane sialoglycoprotein, is another LECsignature molecule that has been initially identified (Breiteneder-Geleff et al. 1999). Podoplanin is expressed in all endothelial cells of the cardinal vein at mouse E11.5 and is later, similarly to VEGFR-3 and LYVE-1, progressively down-regulated in venous endothelial cells, but is continuously expressed in LECs throughout development. Despite its predominant expression in LECs but not in BECs, podoplanin is also expressed in a broad range of cell types including lung type I alveolar cells, ciliary epithelial cells of the eye, choroid plexus cells, osteocytes, and kidney podocytes and was independently cloned and differently named as, for example, OTS8, E11 antigen, RTI40, murine gp38, canine gp40, human gp36, aggrus, and murine PA2.26 (Nose et al. 1990; Wetterwald et al. 1996; Zimmer et al. 1999; Hirakawa et al. 2003; Kato et al. 2003; Ramirez et al. 2003). Consistently, podoplanin knockout mice revealed defects in multiple organs and die perinatally from respiratory failure (Ramirez et al. 2003; Schacht et al. 2003). Notably, podoplanin-deficient mice fail to develop a functional lymphatic system with a severe lymphedema in the extremities (Schacht et al. 2003). A series of recent findings has shown that podoplanin activates a novel platelet receptor, C-type lectinlike receptor (CLEC)-2 of platelet, and has an essential role in blood-lymphatic separation during lymphatic development (see more information below) (Fu et al. 2008; Kato et al. 2008; Bertozzi et al. 2010a,b; Suzuki-Inoue et al. 2007, 2010; Uhrin et al. 2010; SuzukiInoue 2011). Moreover, some lymphatic vessels were found to express a high level of podoplanin (LEC ${ }^{\text {podo-high }}$ ) and the others a low level of podoplanin ( $\mathrm{LEC}^{\text {podo-low }}$, and these two subpopulations differentially recruit CCR10positive $\mathrm{T}$ lymphocytes during the inflammation response (Kriehuber et al. 2001; Wick et al. 2008).

Chicken ovalbumin upstream transcription factor (COUP-TF) II is an orphan nuclear receptor expressed in the embryonic veins from E8.5 (Lin et al. 2010). The critical role of COUP-TFII in vascular development was identified from a knockout mouse study (You et al. 2005). COUP-TFII deletion resulted in abnormal arterialization of the veins by misexpression of the Notch pathway genes in the venous compartment, whereas ectopic COUP-TFII overexpression in vivo induced the excessive venous endothelial phenotype at the expense of arterial endothelial cells (You et al. 2005). Importantly, 
I. Choi et al.

COUP-TFII has been identified as an interacting partner of Proxl in vitro and in vivo, and the functional interaction between the two cellfate regulators was proposed to constitute an essential part in the program specifying LEC fate (Lee et al. 2009; Yamazaki et al. 2009; Srinivasan et al. 2010). Supporting this notion, conditional ablation of COUP-TFII at an early embryonic stage blocked the LEC-fate specification of the venous endothelial cells and formation of lymphatic vessels (Lin et al. 2010). COUP-TFII deficiency at a late developmental stage not only reversed the LEC differentiation program, ending up regaining the blood endothelial cell fate, but also impaired lymphatic vessel sprouting, indicating the essential roles of COUP-TFII in lymphatic development (Lin et al. 2010). Notably, it has been shown that the VEGF coreceptors neuropilin (NRP)-1 and NRP-2 are differentially expressed in endothelial cell lineages: Whereas NRP-1 is selectively expressed in the arterial compartment, NRP-2 is predominantly in venous and lymphatic endothelial cells (Herzog et al. 2001; Neufeld et al. 2002; Yuan et al. 2002). COUP-TFII plays a key part in this endothelial cell-lineage-specific expression of NRP-1 and NRP-2 (You et al. 2005; Lee et al. 2009; Lin et al. 2010).

FOXC2, a Forkhead family transcription factor, is one of the few causative genes associated with human lymphatic disorder and malformation to date and is found to be responsible for lymphedema-distichiasis (double row of eye lashes) syndrome by multiple groups (Fang et al. 2000; Erickson 2001; Erickson et al. 2001; Finegold et al. 2001; Bahuau et al. 2002; Brice et al. 2002; Traboulsi et al. 2002; Kriederman et al. 2003; Fabretto et al. 2010). Foxc2 is expressed in both arterial and lymphatic endothelial cells and, along with Foxc1, is required for arterial specification and normal lymphatic sprouting from the vein during development (Dagenais et al. 2004; Seo et al. 2006; Kume 2009). Importantly, Foxc2 and Vegfr3 were found to cooperate in lymphatic vascular patterning during lymphatic development, and Foxc2-deficient mice showed abnormal lymphatic patterning, increased mural cell investment, absence of lymphatic valves, and lymphatic dysfunction (Petrova et al. 2004). Lymphatics in Foxc2 knockout mice up-regulated PDGF-B, abnormally recruited excessive pericytes and smooth muscle cells (SMC), and were surrounded by a thicker layer of basement-membrane protein collagen type IV (Petrova et al. 2004). Moreover, Foxc2 has been shown to have a key role in lymphatic maturation (Norrmen et al. 2009) (see below for details). Altogether, Foxc2 has important roles throughout lymphatic development.

\section{Prox1: The Master Regulator for Lymphatic Development}

Prox1 was originally isolated by its protein sequence homology to the Drosophila protein Prospero (Oliver et al. 1993; Tomarev et al. 1996). The Prospero gene was first cloned by its mutant phenotype in neuronal lineage cellfate specification (Doe et al. 1991; Vaessin et al. 1991). When a neuroblast cell divides during development, one daughter cell remains as a stem cell, and the other daughter cell undergoes neuronal differentiation to become a neuron or glia. During this process, only one daughter cell receives Prospero protein through an asymmetrical segregation of the protein and undergoes further differentiation (Doe et al. 1991; Vaessin et al. 1991). Despite a high protein sequence similarity between Prospero and Prox1, the amino acid motif responsible for this asymmetric segregation of Prospero seems not present in Prox1 (Hong and Detmar 2003), and asymmetric segregation of Proxl has not been reported to date. Like Prospero, Prox1 is also expressed in many other organs, such as the liver, brain, pancreas, heart, eye lens, ear sensory epithelium, taste bud, and retina (Oliver et al. 1993; Wigle et al. 1999; Wigle and Oliver 1999; SosaPineda et al. 2000; Govindarajan and Overbeek 2001; Miura et al. 2003; Bermingham-McDonogh et al. 2006; Dudas et al. 2006; Edqvist et al. 2006; Laerm et al. 2007; Kirjavainen et al. 2008; Risebro et al. 2009). Interestingly, the cell-fate-specifying function of Prospero seems to have been inherited by Proxl and appears to be the common functional theme of Prox1 in such diverse cell types. For example, 
Lymphatics, the Other Circulatory System

Prox1 induces cell cycle arrest in developing lens and directs differentiation of the lens fiber cells (Wigle et al. 1999). Similarly, Proxl induces the exit of retinal progenitor cells from the cell cycle and promotes horizontal cell differentiation (Dyer et al. 2003). Prox1 overexpression resulted in enhanced neuronal differentiation, whereas knockdown of Proxl impaired the generation of neurons (Karalay et al. 2011). Notably, Prospero has been shown to regulate cell cycle progression because loss of Prospero induced aberrant expression of cell cycle genes such as cyclin A (cycA), cyclin E ( $c y c E)$, and string ( $s r g$ ) and resulted in increased mitotic activity ( $\mathrm{Li}$ and Vaessin 2000). Conversely, overexpression of Prospero causes repression of multiple cell cycle genes and premature termination of cell division ( $\mathrm{Li}$ and Vaessin 2000). Although Prox1 regulates the expression of CDKN1C/ p57 ${ }^{\text {kip2 }}$, a major cell cycle inhibitor, in LECs as well as other cell types (Wigle et al. 1999; Govindarajan and Overbeek 2001; Petrova et al. 2002; Pan et al. 2009), there has not been any report detailing cell cycle regulation during Prox1induced LEC differentiation.

Recent studies have provided more information on the regulation and function of Prox1. SRY-related HMG-box 18 (Sox18), a member of the F-group of Sox transcription factors, has been identified to bind upstream of PROX1 and up-regulate Prox1 expression (François et al. 2008). Moreover, mice carrying a natural Sox18-dominant-negative mutation fail to initiate Proxl up-regulation in venous endothelial cells during development and to develop a normal lymphatic system (François et al. 2008). Importantly, humans with mutations in Sox18 develop a blood/lymphatic vascular disease, hypotrichosis-lymphedematelangiectasia (HLT), which is characterized by alopecia, hemorrhage, and lymphedema (Irrthum et al. 2003). Sox7 and Sox17 were also found to regulate lymphatic development as modifiers of Sox18 (Hosking et al. 2009), and mutation in Sox17 has suggested it to be a candidate gene for human primary lymphedema (Ferrell et al. 2008).

In addition to Sox18, NF- $\mathrm{kb}$ (Flister et al. 2010, 2011), TGF- $\beta$ (Oka et al. 2008), inter- leukin-3 (Groger et al. 2004), and VEGF-C (Sivakumar et al. 2008) have been shown to regulate Prox1 in endothelial cells, but their roles in lymphatic development need to be established. Moreover, regulators of Prox1 have been reported in other types of cells. In colon cancer cells (Petrova et al. 2008) and hippocampus cells (Karalay et al. 2011), Proxl is regulated by the Wnt signal through two binding sites of $\beta$-catenin/TCF found in the Prox 1 enhancer region at $-49 \mathrm{~kb}$ and $-43 \mathrm{~kb}$ upstream of the Proxl start codon, which induce colon cancer progression and neuronal cell differentiation, respectively. Mash1 (Torii et al. 1999) and Foxe3 (Medina-Martinez et al. 2005) were found to regulate Prox1 expression in the nervous system and lens, respectively.

A recent study has identified that the Prox 1 mRNA contains an extraordinarily long $3^{\prime}$ untranslated region (UTR) (Yoo et al. 2010). Whereas the human Proxl open reading frame (ORF) is $\sim 2.2 \mathrm{~kb}$ long and encodes a 737-amino-acid-long protein (Oliver et al. 1993; Tomarev et al. 1998), the PROX1 gene is $\sim 50 \mathrm{~kb}$ long and expresses $\sim 8$-kb-long transcripts in most organs and tissues, except retina (Tomarev et al. 1998) and testis (Steffensen et al. 2004), which express an $\sim 2.3$-kb Prox 1 mRNA. Detailed molecular analyses show that Prox1 mRNA harbors an $~ 5.4-k b-l o n g ~ 3^{\prime}$ UTR and that this evolutionarily conserved region of the gene is found to be subjected to posttranscriptional regulation by HuR (Yoo et al. 2010) and microRNAs (Kazenwadel et al. 2010; Pedrioli et al. 2010), indicating that Prox1 may be regulated by multiple physiological and pathological signals and stimuli.

\section{Separation of Blood and Lymphatic Vessels}

After migration of the lymphatically committed venous endothelial cells, the next key developmental process is a coordinate separation of the rudimentary lymphatic vessels from blood circulation to avoid blood-lymphatic mixing. Interestingly, blood-lymphatic mixing phenotypes have been reported in several mutant mice lacking SYK (Cheng et al. 1995; Turner et al. 1995), SLP-76 (Abtahian et al. 2003), or 
I. Choi et al.

PLC $\gamma$-2 (Wang et al. 2000). These findings have provided important insights into the essential roles of the hematopoietic compartment in lymphatic development because the expression of these genes (SYK and SLP-76) is restricted in hematopoietic lineage cells. Supporting this notion, RUNX1 knockout mice that fail to undergo definitive hematopoiesis also reveal similar blood-lymphatic mixing phenotypes during early lymphatic development (Srinivasan et al. 2007). However, various genetic and cell lineage tracing experiments ruled out the possibility of direct incorporation of hematopoietic cells into growing lymphatic vessels during development (Srinivasan et al. 2007). Therefore, the question of how the hematopoiesis genes control lymphatic development, especially lymphatic separation from blood circulation, remained unanswered until two reports brought forward a critical clue that links podoplanin to platelet activation: Suzuki-Inoue and colleagues demonstrated a novel Sykdependent mechanism of platelet activation by CLEC-2 (Suzuki-Inoue et al. 2006) and O-glycan-dependent physical interaction of podoplanin with CLEC-2 (Suzuki-Inoue et al. 2007). These pioneering findings were followed by a series of molecular and genetic studies confirming the role of podoplanin/CLEC-2 interaction in lymphatic development. Notably, endothelial cell O-glycan deficiency caused blood/lymphatic misconnection in mouse $(\mathrm{Fu}$ et al. 2008), and podoplanin or CLEC-2 knockout mice showed the blood-lymphatic mixing phenotype of mice lacking SYK, SLP-76, or PLC $\gamma$-2 (Bertozzi et al. 2010a,b; Suzuki-Inoue et al. 2010; Uhrin et al. 2010). Together, these studies show that the platelets mediate blood and lymphatic separation by activation of the CLEC-2 receptor following interaction with the podoplanin ligand found on the surface of LECs.

Plasticity of Lymphatic Endothelial Cell Fate-Lymphatic Equilibrium

Heterogeneity and plasticity are the two remarkable features of endothelial cells (Lee et al. 2010b). Various genetic and molecular studies using gain-of-function (GOF) or loss-of-function (LOF) mutations have shown that endothelial cells maintain astonishing flexibilities in electing their arteriovenous-lymphatic cell fates. For example, ectopic Notch expression in the venous compartment induces the arterial phenotypes at the expense of the veins, and, conversely, inhibition of Notch brings abnormal venous phenotypes onto the arterial vessels (Lawson et al. 2001, 2002; Lin et al. 2007; Benedito and Adams 2009). Similarly, when the venous endothelial cell-specific nuclear receptor COUP-TFII is genetically deleted, the venous compartment displays the arterial-specific characteristics such as upregulation of the arterial markers and functional generation of hematopoietic cell clusters (You et al. 2005). This kind of endothelial cell fate plasticity can be also discovered in the lymphatic compartment. Studies of the genomewide transcriptional profiles of human dermal BECs versus LECs revealed that more than $\sim 95 \%$ of genes are comparatively expressed in two subtypes of endothelial cells (Petrova et al. 2002; Podgrabinska et al. 2002; Hirakawa et al. 2003). However, when overexpressed in BECs, Proxl induces lymphatic reprogramming of the cells by up-regulating LEC-specific genes and simultaneously down-regulating BECspecific genes (Hong et al. 2002; Petrova et al. 2002; Hirakawa et al. 2003). Conversely, Prox1 inhibition in embryonic or postdevelopmental LECs results in loss of lymphatic cell fate in vivo and in vitro (Johnson et al. 2008; Lee et al. 2009). Therefore, LEC identity appears to be highly plastic and reversible, and Prox1 is required to maintain LEC identity (Johnson et al. 2008; Lee et al. 2009).

In fact, it has been proposed that the three endothelial cell fate regulators-namely, Notch (arterial) (Shawber et al. 2007), COUP-TFII (venous) (You et al. 2005), and Proxl (lymphatic) (Wigle and Oliver 1999)_are all expressed in LECs and cross-regulate one another (Lee et al. 2009; Kang et al. 2010). Notch, which is selectively expressed in arterial endothelial cells and acts as a downstream effector of VEGF-induced arterialization signal (Lawson et al. 2001, 2002; Weinstein and 
Lymphatics, the Other Circulatory System

Lawson 2002; Lanner et al. 2007; Siekmann and Lawson 2007), represses the expression of COUP-TFII, Prox1, and podoplanin through Heyl (Kang et al. 2010). COUP-TFII, a nuclear receptor that is selectively expressed in the venous compartment, has been shown to interact physically and functionally with Prox 1 in LECs to direct a developmental program that specifies LEC fate (Lee et al. 2009; Yamazaki et al. 2009; Kang et al. 2010; Srinivasan et al. 2010). Interestingly, Proxl and COUP-TFII concertedly suppress VEGF signaling by downregulating the expression of the major VEGF receptors VEGFR-2 and NRP-1 (Kang et al. 2010). Consistent with these in vitro findings, podoplanin and Notch1 are found to be conversely regulated in lymphatic vessels in vivo: LECs with low Notch1 expression tend to express more podoplanin protein, and vice versa. Interestingly, however, knockdown of Notch or its ligand Dll4 in zebrafish embryos impairs lymphangiogenesis, in particular, the initial budding of lymphatically differentiating venous endothelial cells, and lymphatic vessel navigation (Geudens et al. 2010), suggesting that despite its repressive role of lymphatic phenotypes, Notch signal is still required for the optimal lymphatic development. Together, these studies proposed a new concept that the expression of the three cell fate controllers is regulated by an exquisite feedback mechanism working in LECs and that LEC fate may be viewed as a phenotypic consequence of Prox1directed "lymphatic equilibrium" among the cell fate regulators.

Postnatal lymphatic plasticity also needs to be addressed. LEC-fate plasticity is most often associated with various pathological conditions (Lee et al. 2010b). For example, the expression of VEGFR-3 is detectable in BECs before lymphatic sprouting, but after then is restricted to LECs, thus serving as an important LECsignature gene in normal tissues (Jeltsch et al. 1997). However, abnormal expression of VEGFR-3 in BECs has been reported in various malignant tumors and granulation tissues (Partanen et al. 1999; Valtola et al. 1999; Witmer et al. 2001; Nakamura et al. 2003). Thus, VEGFR-3 expression in BECs was postulated to be a new microvascular progression marker that mediates lymphangiogenic factor-induced neovascularization (Clarijs et al. 2002). In addition, tumor-associated LECs were found to express several hundreds of genes differentially compared to normal, inflammatory cytokines or mitogen-activated LECs (Clasper et al. 2008; Royston and Jackson 2009). For example, tumor-associated LECs were found to up-regulate functionally significant molecules including the tight junction endothelial-specific adhesion molecule (ESAM), endoglin (CD105), leptin receptor, and CD200. Although exclusively expressed in BECs in normal tissue, ESAM was up-regulated in tumor lymphatics and linked with nodal metastasis (Clasper et al. 2008). Moreover, another BEC-signature molecule, CD34, was reported to be expressed by tumor-associated LECs in colon, breast, lung, and skin tumors, and a majority of intratumoral lymphatics revealed a complete colocalization of CD34 with various LEC markers such as LYVE-1, podoplanin, and Proxl (Fiedler et al. 2006).

\section{Lymphatic Vessel Maturation and Postdevelopmental Remodeling}

In addition, Foxc2 has recently been shown to control formation and maturation of lymphatic collecting vessels through cooperation with NFATc1 (Norrmen et al. 2009). As lymphatic vessels mature during development, the lymphatic capillary plexus undergoes substantial morphological remodeling and acquires distinct characteristics of the collecting lymphatic vessels such as even diameter, mural cell recruitment, intraluminal valves, and little branching (Norrmen et al. 2009). Moreover, maturing lymphatic vessels were found to down-regulate some of the lymphatic capillary markers: For example, the high expression of Foxc2 and Prox1 can be continuously detected in LECs of bileaflet luminal valves but is somewhat reduced in collecting lymphatic vessel endothelial cells (Norrmen et al. 2009).

In addition to its role in the arteriovenouslymphatic cell fate specification, the Notch signal pathway is also known to regulate vascular 
I. Choi et al.

morphogenesis by controlling angiogenic sprouting (Noguera-Troise et al. 2006; Ridgway et al. 2006; Hellstrom et al. 2007; Hofmann and Iruela-Arispe 2007; Siekmann and Lawson 2007). The main role of Notch in endothelial cells appears to be to regulate blood vessel quiescence and laterally inhibit new sprouting partly by down-regulating VEGFR-2 during angiogenesis, placing Notch signal as a negative regulator of VEGF-stimulated angiogenesis (Phng and Gerhardt 2009). This function of Notch in angiogenesis has been recently extended to the lymphatic compartment. Notch negatively regulates postdevelopmental lymphangiogenesis: Notch inhibition synergizes VEGF-induced lymphatic sprouting in vitro and in vivo, and forced expression of its ligand Dll4 in LECs promoted adoption of the tip cell position, suggesting that the Notch signal pathway negatively regulates lymphatic sprouting and induces stalk cell specification (Niessen et al. 2011; Zheng et al. 2011). Importantly, Notch pathway components are found more abundantly expressed in LECs over BECs, and this higher baseline activity of Notch was hypothesized to lead to a lower sensitivity of LECs than BECs to VEGF-activated vascular sprouting (Zheng et al. 2011).

\section{LYMPHEDEMA AND LYMPHATIC DISEASES}

"Lymphedema" refers to chronic tissue swelling in the face, arms, legs, or abdominal walls caused by accumulation of interstitial fluids mainly due to lymphatic dysfunction caused by lymphatic dysplasia, malformation, misconnection, and obstruction, as well as absence of functional lymphatic valves. Lymphedema is classified as primary (genetic) or secondary (acquired) lymphedema (Browse and Stewart 1985; Fonkalsrud 1994; Mortimer 1998; Rockson 1998; Child et al. 1999).

\section{Primary Lymphedema}

Primary lymphedema arises from genetic defects that interfere with normal lymphatic development and, despite its highly variable clinical manifestation, can be traditionally divided into three groups depending on the age of onset: congenital lymphedema (at birth), lymphedema praecox (early onset), and lymphedema tarda (late onset) (Allen 1934).

Congenital lymphedema includes all forms of lymphedema that are clinically evident at birth and accounts for $10 \%-25 \%$ of all primary lymphedema. Congenital lymphedema manifests more often with females than males, in lower than upper extremities, and in single than both legs. A subgroup of congenital lymphedema, namely, Milroy disease (Milroy 1892, 1928), has been initially linked to the VEGFR-3 locus on distal chromosome 5q, and later various mutations in the VEGFR-3 gene have been identified in patients with this disorder (Evans et al. 1999; Irrthum et al. 2000; Connell et al. 2009). Mice with VEGFR-3 mutations were shown to develop primary lymphedema, confirming the underlying etiology of the disease (Karkkainen et al. 2000).

"Lymphedema praecox," often called Meige's disease, collectively refers to all lymphedema with onset at ages 1 through 35, most often at puberty, and thus includes the majority $(60 \%-80 \%)$ of primary lymphedema. Notably, females are affected four times more often than males. Generally, Meige's disease patients display dysplastic, smaller, and fewer lymphatic vessels compared to healthy individuals. Because the classification for lymphedema was established based on the onset age of the diseases, not on their genetics, pathophysiology, or etiology, the terms "lymphedema praecox" or "Meige's disease" have been confusing and impeding to better understand, diagnose, and treat the diseases. In fact, hereditary lymphedema praecox is frequently associated with several other anomalies including distichiasis, extradural cysts, vertebral anomalies, cerebrovascular malformation, yellow nails, and sensorineural hearing loss (Wheeler et al. 1981).

Lymphedema-distichiasis syndrome, a subset of lymphedema praecox, is a rare autosomal dominant disease characterized by swollen limbs and double rows of eyelashes (Robinow et al. 1970; Hoover and Kelley 1971; Jester 1977) and has been genetically linked to the FOXC2 gene, which encodes a member of the 
Lymphatics, the Other Circulatory System

Forkhead/Winged-Helix family of transcription factors that are involved in diverse developmental pathways (Fang et al. 2000; Bell et al. 2001; Finegold et al. 2001). Consistently, Foxc2deficient mice display lymphatic dysfunction, including abnormal mural cell coverage on lymphatic capillaries, defective valves of the collecting lymphatic vessels, and irregular lymphatic patterning (Petrova et al. 2004). In addition, hypotrichosis-lymphedema-telangiectasia syndrome, another subset of lymphedema praecox, has been described to be associated with hypotrichosis and telangiectasia (Irrthum et al. 2003; Hosking et al. 2009). Mutations of the SRYrelated transcription factor SOX18, which acts upstream of PROX1, were found to be responsible for both recessive and dominant forms of this disease. Recently, two more genes (GJC2 and CCBE1) were identified to be causally associated with lymphedema. The GJC2 gene encodes connexin 47, an intercellular gap junction protein, and mutations in the protein were postulated to cause impaired gap junction activities and result in defective lymphatic flow (Ferrell et al. 2010). CCBE1 has been shown to play a role in lymphatic sprouting during zebrafish development, and mutations in CCBE1 were found in patients with Hennekam lymphangiectasia-lymphedema syndrome (Alders et al. 2009; Hogan et al. 2009).

The third type of primary lymphedema is called lymphedema tarda, which manifests the lymphedema symptom only at late stages of life, usually after age 35, and constitutes $\sim 10 \%$ of all primary lymphedema (Ohara and Taneichi 1973; Segal and Turner 1976; Vieras and Boyd 1976; Majeski 1986; Burgos and Luginbuhl 2009). This form of lymphedema displays a tortuous, hyperplastic pattern of lymphatic vessels characterized by an increase in diameter and number. Notably, the patients with this form of lymphedema often lack functional lymph valves.

Despite its historical significance and convenient organization, this traditional onset-agedependent classification bears significant limitations and drawbacks because it does not convey the precise information of the disease and thus can be confusing and even hampering to basic research and clinical practice for lymphedema patients, especially in the era of molecular medicine. Luckily, several attempts have been made to establish new classifications and categorizations of primary lymphedema based on clinical phenotypes, familiar history, onset age, associated abnormalities, local and systemic involvement, and underlying genetics (Szuba and Rockson 1998; Miller et al. 1999; Board and Harlow 2002; Northup et al. 2003; Honnor 2008; Connell et al. 2010).

\section{Secondary Lymphedema}

Secondary or acquired lymphedema is caused by functionally compromised lymphatics owing to infection, surgery, radiation, or compression. In the advanced countries, the majority of secondary lymphedema is observed among cancer patients who undergo various radiation therapies following lymphadenectomy. Lymphadenectomy is a surgical lymph node dissection and a common procedure for assessing the stages of tumors. Although it is an essential practice, it inevitably destroys and obstructs lymphatic flows and thus renders patients at a high increased risk of lymphedema. Studies report that $25 \%-56 \%$ of breast cancer patients develop mild-to-severe lymphedema after cancer treatment (Pezner et al. 1986; Kiel and Rademacker 1996; Hinrichs et al. 2004; Ozaslan and Kuru 2004). Despite recent adoption of the sentinel lymph node biopsy technique, which removes only tumor-draining lymph nodes and thus significantly reduces the incidence of surgical lymphedema, cancer therapy-associated secondary lymphedema remains the most common complication for cancer survivors.

Worldwide, the most common cause of secondary lymphedema is filariasis, direct infection of lymphatic vessels by mosquito-borne parasitic nematodes like Wuchereria bancrofti (Shenoy 2006; Hoerauf 2008; Bockarie et al. 2009; Pfarr et al. 2009). More than 100 million people in tropical Africa and Asia are currently affected by lymphedema filariasis, associated with infection-induced inflammatory responses that cause lymphatic hyperplasia and obstructions, followed by tissue fibrosis, 
I. Choi et al.

hypercellularity, fat accumulation, and secondary infection. Lymphedema can also be caused by vein stripping, vascular surgery, lipectomy, and burns. Lymphedema presents severe social, economic, and psychological burdens to patients and their families, and, unfortunately, no cures are currently available for this disfiguring disease.

\section{Lymphedema Therapy-Beyond Physical Compression}

To date, several factors have been reported to stimulate lymphangiogenesis of both cultured LECs and animals, including VEGF-A, VEGFC, VEGF-D, FGF-2, PDGF, IGF-1, IGF-2, Angiopoietin-1, and HGF (Adams and Alitalo 2007; Karpanen and Alitalo 2008; Tammela and Alitalo 2010; Lahteenvuo et al. 2011; Norrmen et al. 2011), and the list is growing rapidly. Among them, VEGF-C has been best characterized and is considered to be the most promising therapeutic agent to treat human lymphedema (Norrmen et al. 2011). Administration of a VEGF-C-expressing adenovirus enhanced generation of functional lymphatic vessels in Chy mutant mice (Karkkainen et al. 2001), and adenoviral delivery of VEGF-C in normal skin or at the edge of epigastric skin flaps in mice strongly induced lymphangiogenesis (Enholm et al. 2001; Saaristo et al. 2004). In addition, recombinant VEGF-C was shown to be sufficient to activate in vivo lymphangiogenesis and reversed the symptoms of lymphedema in rabbit ears (Szuba et al. 2002); VEGF-C gene therapy stimulated postnatal lymphangiogenesis and thus ameliorated secondary lymphedema in animal models (Yoon et al. 2003). More recently, using a newly established mouse model in which the axillary lymph nodes were removed to better recapitulate human breast cancer lymphadenectomy, Tammela et al. (2007) have shown that collecting lymphatic vessels could be efficiently regenerated and connected to transplanted lymph node in the lymphedema area. Adenoviral delivery of VEGF-C or VEGF-D into lymph-node-excised mice resulted in robust proliferation of lymphatic capillaries, followed by remodeling, differentiation, and maturation to establish functional collecting lymphatic vessels that are equipped with uniform endothelial cell-cell junctions and intraluminal valves, as well as mural cell investment (Tammela et al. 2007). Moreover, this experimental paradigm has been further extended to a non-rodent model: Lahteenvuo et al. (2011) evaluated the therapeutic effect of autologous lymph node transfer combined with adenoviral expression of VEGF-C or VEGF-D in a newly established porcine model of lymphedema in the inguinal area. Consistent with the data from the rodent model, both growth factors stimulated robust lymphangiogenesis in the defect area, and postoperative lymphatic drainage was dramatically improved, with the structure of the transferred lymph nodes best preserved in the VEGF-Ctreated pigs. Taken together, VEGF-C provides the most promising therapeutic efficacy against lymphedema to date, and further development of VEGF-C as a therapeutic drug is eagerly awaited by human lymphedema patients.

\section{Lymphangioleiomyomatosis (LAM)}

Lymphangioleiomyomatosis (LAM) is a rare destructive lung disease that is etiologically associated with excessive proliferation of LECs (lymphangio) and smooth muscle cells (leiomyoma) throughout the lungs including bronchioles, alveolar septa, perivascular spaces, and parenchyma (Hohman et al. 2008; Darling et al. 2010; Kristof 2010; Kwiatkowski 2010; Seyama et al. 2010). The abnormal proliferation of these two types of cells (LECs and SMCs) in LAM results in both obstruction of airways and tissue fluid drainage, causing pulmonary cyst formation, pneumothorax, and chylous pleural effusion with respiratory failure, needing lung transplantation. LAM occurs in about onethird of child-bearing-age women with tuberous sclerosis complex (TSC), which is caused by various mutations in either TSC1 or TSC2 genes. Importantly, LAM patients express a high level of the potent lymphangiogenic factor VEGF-D in their blood serums, which may partly explain the excessive LEC proliferation in their lungs. Because mutations in TSC1/2 
Lymphatics, the Other Circulatory System

lead to abnormal activation of the downstream effector mTOR, rapamycin, a chemical inhibitor for mTOR, was found to be beneficial to some LAM patients (Darling et al. 2010; Kristof 2010).

Lymphatic Reprogramming of Vascular Endothelial Cells by Kaposi's Sarcoma Herpes Virus (KSHV)

Kaposi's sarcoma (KS) is an endothelial cell tumor and the most common neoplasm among HIV-positive individuals (Aguilar and Hong 2009). Although it was first described by Moritz Kaposi in 1872 (Kaposi 1872), KS did not receive much medical and scientific attention until the 1980s, when acquired immune deficiency syndrome (AIDS) became endemic. In 1994, Kaposi's sarcoma associated herpes virus (KSHV) was identified to be the causing agent for KS (Chang et al. 1994), and since then, studies of the pathogenesis of KS and KSHV have been extensively performed. Despite original studies that pointed to endothelial cells as the origin of KS tumor cells 40 years ago (Dayan and Lewis 1967), the histogenetic origin of KS tumor cells has been elusive to define for many years because of the mixed gene expression profile of KS tumor cells: KS tumor cells were thought to express BEC-specific genes, but as new lymphatic research tools became available from the late 1990s, lymphatic characteristics of KS tumor cells became evident (Aguilar and Hong 2009). Later, it was found that KS's dual phenotypes of BECs and LECs were attributed to lymphatic reprogramming of BECs by KSHV (Carroll et al. 2004; Hong et al. 2004; Wang et al. 2004): When KSHV infects BECs, it activates the expression of Prox1, the master control gene of lymphatic differentiation, and subsequently induces lymphatic reprogramming of BECs (Carroll et al. 2004; Hong et al. 2004; Wang et al. 2004), suggesting that this oncogenic virus reactivates the otherwise silenced embryonic endothelial differentiation program in adult cells. It is not yet understood why KSHV induces the Prox1mediated lymphatic reprogramming of vascular endothelial cells, and studies of its molecular mechanism will surely advance our understanding of endothelial cell plasticity and heterogeneity in health and disease.

\section{CONCLUDING REMARKS}

Since its original description by Hippocrates, the lymphatic system has been neglected by both scientific and medical communities because of its vagueness in structure and function. Even after its rediscovery 400 years ago, the lymphatic system was considered a secondary vascular system that supports the blood vascular system. However, a series of landmark discoveries in lymphatic research has significantly advanced our understanding of not only the organogenesis, function, and anatomic structure of the system, but also the cellular and molecular biology of LECs. In particular, substantial attention has been given to the elucidation of the molecular control of physiological and pathological lymphangiogenesis, reevaluating its essential roles in human health and wellbeing. This paradigm shift simultaneously forced us to take a brand-new look at the lymphatic system as the other, not the secondary, vascular system. Considering the vital functions that the lymphatic system engages in and how little knowledge we have regarding the system, lymphatic research is truly a gold mine that invites ambitious young scientists and clinicians.

\section{ACKNOWLEDGMENTS}

This work is supported by funding from the American Cancer Society, National Institute of Health/National Heart, Lung, and Blood Institute (NHLBI), and the March of Dimes Foundation. The authors claim no conflict of interest.

\section{REFERENCES}

\footnotetext{
Abtahian F, Guerriero A, Sebzda E, Lu MM, Zhou R, Mocsai A, Myers EE, Huang B, Jackson DG, Ferrari VA, et al. 2003. Regulation of blood and lymphatic vascular separation by signaling proteins SLP-76 and Syk. Science 299: 247-251.

Adams RH, Alitalo K. 2007. Molecular regulation of angiogenesis and lymphangiogenesis. Nat Rev Mol Cell Biol 8: 464-478.
} 
I. Choi et al.

Aguilar B, Hong YK. 2009. The origin of Kaposi sarcoma tumor cells. Research Signpost, Trivandrum, India.

Alders M, Hogan BM, Gjini E, Salehi F, Al-Gazali L, Hennekam EA, Holmberg EE, Mannens MM, Mulder MF Offerhaus GJ, et al. 2009. Mutations in CCBE1 cause generalized lymph vessel dysplasia in humans. Nat Genet 41: 1272-1274.

Alitalo K. 2002. Growth factors controlling angiogenesis and lymphangiogenesis. Ugeskr Laeger 164: 3170-3172.

Alitalo K, Carmeliet P. 2002. Molecular mechanisms of lymphangiogenesis in health and disease. Cancer Cell 1: 219-227.

Allen EV. 1934. Lymphedema of the extremities. Classification, etiology and differential diagnosis. A study of three hundred cases. Arch Intern Med 54: 606-624.

Asellius G. 1627. De lactibus sive lacteis venis. Mediolani, Milan.

Bahuau M, Houdayer C, Tredano M, Soupre V, Couderc R, Vazquez MP. 2002. FOXC2 truncating mutation in distichiasis, lymphedema, and cleft palate. Clin Genet 62: 470-473.

Baluk P, Fuxe J, Hashizume H, Romano T, Lashnits E, Butz S, Vestweber D, Corada M, Molendini C, Dejana E, et al 2007. Functionally specialized junctions between endothelial cells of lymphatic vessels. J Exp Med 204: 2349-2362.

Banerji S, Ni J, Wang SX, Clasper S, Su J, Tammi R, Jones M, Jackson DG. 1999. LYVE-1, a new homologue of the CD44 glycoprotein, is a lymph-specific receptor for hyaluronan. J Cell Biol 144: 789-801.

Bell R, Brice G, Child AH, Murday VA, Mansour S, Sandy CJ, Collin JR, Brady AF, Callen DF, Burnand K, et al. 2001. Analysis of lymphoedema-distichiasis families for FOXC2 mutations reveals small insertions and deletions throughout the gene. Hum Genet 108: 546-551.

Benedito R, Adams RH. 2009. Development. Aorta's cardinal secret. Science 326: 242-243.

Bermingham-McDonogh O, Oesterle EC, Stone JS, Hume CR, Huynh HM, Hayashi T. 2006. Expression of Proxl during mouse cochlear development. J Comp Neurol 496: $172-186$

Bertozzi CC, Hess PR, Kahn ML. 2010a. Platelets: Covert regulators of lymphatic development. Arterioscler Thromb Vasc Biol 30: 2368-2371.

Bertozzi CC, Schmaier AA, Mericko P, Hess PR, Zou Z, Chen M, Chen CY, Xu B, Lu MM, Zhou D, et al. 2010b. Platelets regulate lymphatic vascular development through CLEC-2-SLP-76 signaling. Blood 116: 661-670.

Board J, Harlow W. 2002. Lymphoedema 2: Classification, signs, symptoms and diagnosis. Br J Nurs 11: 389-395.

Boardman KC, Swartz MA. 2003. Interstitial flow as a guide for lymphangiogenesis. Circ Res 92: 801-808.

Bockarie MJ, Taylor MJ, Gyapong JO. 2009. Current practices in the management of lymphatic filariasis. Expert Rev Anti Infect Ther 7: 595-605.

Breiteneder-Geleff S, Soleiman A, Kowalski H, Horvat R, Amann G, Kriehuber E, Diem K, Weninger W, Tschachler E, Alitalo K, et al. 1999. Angiosarcomas express mixed endothelial phenotypes of blood and lymphatic capillaries: Podoplanin as a specific marker for lymphatic endothelium. Am J Pathol 154: 385-394.
Brice G, Mansour S, Bell R, Collin JR, Child AH, Brady AF, Sarfarazi M, Burnand KG, Jeffery S, Mortimer P, et al. 2002. Analysis of the phenotypic abnormalities in lymphoedema-distichiasis syndrome in 74 patients with FOXC2 mutations or linkage to 16q24. J Med Genet 39: $478-483$.

Browse NL, Stewart G. 1985. Lymphoedema: Pathophysiology and classification. J Cardiovasc Surg (Torino) 26: 91-106.

Burgos JA, Luginbuhl A. 2009. Images in clinical medicine. Lymphedema tarda. N Engl J Med 360: 1015.

Carroll PA, Brazeau E, Lagunoff M. 2004. Kaposi's sarcomaassociated herpesvirus infection of blood endothelial cells induces lymphatic differentiation. Virology 328: 7-18.

Chang Y, Cesarman E, Pessin MS, Lee F, Culpepper J, Knowles DM, Moore PS. 1994. Identification of herpesvirus-like DNA sequences in AIDS-associated Kaposi's sarcoma. Science 266: 1865-1869.

Cheng AM, Rowley B, Pao W, Hayday A, Bolen JB, Pawson T. 1995. Syk tyrosine kinase required for mouse viability and B-cell development. Nature 378: 303-306.

Chikly B. 1997. Who discovered the lymphatic system. Lymphology 30: 186-193.

Child AH, Fau-Beninson J, Sarfarazi M. 1999. Cause of primary congenital lymphedema. Angiology 50: 325-326.

Clarijs R, Schalkwijk L, Hofmann UB, Ruiter DJ, de Waal RMW. 2002. Induction of vascular endothelial growth factor receptor-3 expression on tumor microvasculature as a new progression marker in human cutaneous melanoma. Cancer Res 62: 7059-7065.

Clasper S, Royston D, Baban D, Cao Y, Ewers S, Butz S, Vestweber D, Jackson DG. 2008. A novel gene expression profile in lymphatics associated with tumor growth and nodal metastasis. Cancer Res 68: 7293-7303.

Connell FC, Ostergaard P, Carver C, Brice G, Williams N, Mansour S, Mortimer PS, Jeffery S. 2009. Analysis of the coding regions of VEGFR 3 and VEGFC in Milroy disease and other primary lymphoedemas. Hum Genet 124: $625-631$.

Connell F, Brice G, Jeffery S, Keeley V, Mortimer P, Mansour S. 2010. A new classification system for primary lymphatic dysplasias based on phenotype. Clin Genet 77: 438-452.

Dagenais SL, Hartsough RL, Erickson RP, Witte MH, Butler MG, Glover TW. 2004. Foxc2 is expressed in developing lymphatic vessels and other tissues associated with lymphedema-distichiasis syndrome. Gene Expr Patterns 4: 611-619.

Darling TN, Pacheco-Rodriguez G, Gorio A, Lesma E, Walker C, Moss J. 2010. Lymphangioleiomyomatosis and TSC2 ${ }^{-1-}$ cells. Lymphat Res Biol 8: 59-69.

Das S, Skobe M. 2008. Lymphatic vessel activation in cancer. Ann NY Acad Sci 1131: 235-241.

Dayan AD, Lewis PD. 1967. Origin of Kaposi's sarcoma from the reticulo-endothelial system. Nature 213: 889-890.

Doe CQ, Chu-LaGraff Q, Wright DM, Scott MP. 1991. The prospero gene specifies cell fates in the Drosophila central nervous system. Cell 65: 451-464.

Dougherty PJ, Davis MJ, Zawieja DC, Muthuchamy M. 2008. Calcium sensitivity and cooperativity of permeabilized 
rat mesenteric lymphatics. Am J Physiol Regul Integr Comp Physiol 294: R1524-R1532.

Dudas J, Elmaouhoub A, Mansuroglu T, Batusic D, Tron K, Saile B, Papoutsi M, Pieler T, Wilting J, Ramadori G. 2006. Prospero-related homeobox 1 (Prox1) is a stable hepatocyte marker during liver development, injury and regeneration, and is absent from "oval cells". Histochem Cell Biol 126: 549-562.

Dumont DJ, Jussila L, Taipale J, Lymboussaki A, Mustonen T, Pajusola K, Breitman M, Alitalo K. 1998. Cardiovascular failure in mouse embryos deficient in VEGF receptor-3. Science 282: 946-949.

Dyer MA, Livesey FJ, Cepko CL, Oliver G. 2003. Proxl function controls progenitor cell proliferation and horizontal cell genesis in the mammalian retina. Nat Genet 34: 53-58.

Edqvist PH, Myers SM, Hallbook F. 2006. Early identification of retinal subtypes in the developing, pre-laminated chick retina using the transcription factors Prox1, Lim1, Ap2 $\alpha$, Pax6, Isl1, Isl2, Lim3 and Chx10. Eur J Histochem 50: $147-154$.

Enholm B, Karpanen T, Jeltsch M, Kubo H, Stenback F, Prevo R, Jackson DG, Yla-Herttuala S, Alitalo K. 2001. Adenoviral expression of vascular endothelial growth factor- $\mathrm{C}$ induces lymphangiogenesis in the skin. Circ Res 88: 623-629.

Erickson RP. 2001. Lymphedema-distichiasis and FOXC2 gene mutations. Lymphology 34: 1.

Erickson RP, Dagenais SL, Caulder MS, Downs CA, Herman G, Jones MC, Kerstjens-Frederikse WS, Lidral AC, McDonald M, Nelson CC, et al. 2001. Clinical heterogeneity in lymphoedema-distichiasis with FOXC2 truncating mutations. J Med Genet 38: 761-766.

Evans AL, Brice G, Sotirova V, Mortimer P, Beninson J, Burnand K, Rosbotham J, Child A, Sarfarazi M. 1999. Mapping of primary congenital lymphedema to the 5q35.3 region. Am J Hum Genet 64: 547-555.

Fabretto A, Shardlow A, Faletra F, Lepore L, Hladnik U, Gasparini P. 2010. A case of lymphedema-distichiasis syndrome carrying a new de novo frameshift FOXC2 mutation. Ophthalmic Genet 31: 98-100.

Fang J, Dagenais SL, Erickson RP, Arlt MF, Glynn MW, Gorski JL, Seaver LH, Glover TW. 2000. Mutations in FOXC2 (MFH-1), a forkhead family transcription factor, are responsible for the hereditary lymphedemadistichiasis syndrome. Am J Hum Genet 67: 1382-1388.

Ferrell RE, Kimak MA, Lawrence EC, Finegold DN. 2008. Candidate gene analysis in primary lymphedema. Lymphat Res Biol 6: 69-76.

Ferrell RE, Baty CJ, Kimak MA, Karlsson JM, Lawrence EC, Franke-Snyder M, Meriney SD, Feingold E, Finegold DN 2010. GJC2 missense mutations cause human lymphedema. Am J Hum Genet 86: 943-948.

Fiedler U, Christian S, Koidl S, Kerjaschki D, Emmett MS, Bates DO, Christofori G, Augustin HG. 2006. The sialomucin CD34 is a marker of lymphatic endothelial cells in human tumors. Am J Pathol 168: 1045-1053.

Finegold DN, Kimak MA, Lawrence EC, Levinson KL, Cherniske EM, Pober BR, Dunlap JW, Ferrell RE. 2001. Truncating mutations in OXC2 cause multiple lymphedema syndromes. Hum Mol Genet 10: 1185-1189.
Flister MJ, Wilber A, Hall KL, Iwata C, Miyazono K, Nisato RE, Pepper MS, Zawieja DC, Ran S. 2010. Inflammation induces lymphangiogenesis through up-regulation of VEGFR-3 mediated by NF-кB and Proxl. Blood 115: 418-429.

Flister MJ, Volk LD, Ran S. 2011. Characterization of Prox1 and VEGFR-3 expression and lymphatic phenotype in normal organs of mice lacking p50 subunit of NF-кB. Microcirculation 18: 85-101.

Fonkalsrud EW. 1994. Congenital malformations of the lymphatic system. Semin Pediatr Surg 3: 62-69.

François M, Caprini A, Hosking B, Orsenigo F, Wilhelm D, Browne C, Paavonen K, Karnezis T, Shayan R, Downes M, et al. 2008. Sox18 induces development of the lymphatic vasculature in mice. Nature 456: 643-647.

Fu J, Gerhardt H, McDaniel JM, Xia B, Liu X, Ivanciu L, Ny A, Hermans K, Silasi-Mansat R, McGee S, et al. 2008. Endothelial cell O-glycan deficiency causes blood/lymphatic misconnections and consequent fatty liver disease in mice. J Clin Invest 118: 3725-3737.

Gale NW, Prevo R, Espinosa J, Ferguson DJ, Dominguez MG, Yancopoulos GD, Thurston G, Jackson DG. 2007. Normal lymphatic development and function in mice deficient for the lymphatic hyaluronan receptor LYVE-1. Mol Cell Biol 27: 595-604.

Geudens I, Herpers R, Hermans K, Segura I, Ruiz de Almodovar C, Bussmann J, De Smet F, Vandevelde W, Hogan BM, Siekmann A, et al. 2010. Role of delta-like-4/Notch in the formation and wiring of the lymphatic network in zebrafish. Arterioscler Thromb Vasc Biol 30: 1695-1702.

Goldman J, Conley KA, Raehl A, Bondy DM, Pytowski B, Swartz MA, Rutkowski JM, Jaroch DB, Ongstad EL. 2007. Regulation of lymphatic capillary regeneration by interstitial flow in skin. Am J Physiol Heart Circ Physiol 292: H2176-H2183.

Govindarajan V, Overbeek PA. 2001. Secreted FGFR3, but not FGFR1, inhibits lens fiber differentiation. Development 128: 1617-1627.

Groger M, Loewe R, Holnthoner W, Embacher R, Pillinger M, Herron GS, Wolff K, Petzelbauer P. 2004. IL-3 induces expression of lymphatic markers Prox-1 and podoplanin in human endothelial cells. J Immunol 173: 7161-7169.

Grotte G. 1979. The discovery of the lymphatic circulation. Acta Physiol Scand Suppl 463: 9-10.

Guo R, Zhou Q, Proulx ST, Wood R, Ji RC, Ritchlin CT, Pytowski B, Zhu Z, Wang YJ, Schwarz EM, et al. 2009. Inhibition of lymphangiogenesis and lymphatic drainage via vascular endothelial growth factor receptor 3 blockade increases the severity of inflammation in a mouse model of chronic inflammatory arthritis. Arthritis Rheum 60: 2666-2676.

Harvey NL, Srinivasan RS, Dillard ME, Johnson NC, Witte MH, Boyd K, Sleeman MW, Oliver G. 2005. Lymphatic vascular defects promoted by Proxl haploinsufficiency cause adult-onset obesity. Nat Genet 37: 1072-1081.

Hellstrom M, Phng LK, Hofmann JJ, Wallgard E, Coultas L, Lindblom P, Alva J, Nilsson AK, Karlsson L, Gaiano N, et al. 2007. Dll4 signalling through Notch1 regulates formation of tip cells during angiogenesis. Nature 445: 776-780. 
I. Choi et al.

Helm CL, Zisch A, Swartz MA. 2007. Engineered blood and lymphatic capillaries in 3-D VEGF-fibrin-collagen matrices with interstitial flow. Biotechnol Bioeng 96: 167-176.

Herzog Y, Kalcheim C, Kahane N, Reshef R, Neufeld G. 2001. Differential expression of neuropilin-1 and neuropilin-2 in arteries and veins. Mech Dev 109: 115-119.

Hinrichs CS, Watroba NL, Rezaishiraz H, Giese W, Hurd T, Fassl KA, Edge SB. 2004. Lymphedema secondary to postmastectomy radiation: incidence and risk factors. Ann Surg Oncol 11: 573-580.

Hirakawa S, Hong YK, Harvey N, Schacht V, Matsuda K, Libermann T, Detmar M. 2003. Identification of vascular lineage-specific genes by transcriptional profiling of isolated blood vascular and lymphatic endothelial cells. Am J Pathol 162: 575-586.

Hoerauf A. 2008. Filariasis: New drugs and new opportunities for lymphatic filariasis and onchocerciasis. Curr Opin Infect Dis 21: 673-681.

Hofmann JJ, Iruela-Arispe ML. 2007. Notch signaling in blood vessels: Who is talking to whom about what? Circ Res 100: 1556-1568.

Hogan BM, Bos FL, Bussmann J, Witte M, Chi NC, Duckers HJ, Schulte-Merker S. 2009. Ccbe1 is required for embryonic lymphangiogenesis and venous sprouting. Nat Genet 41: 396-398.

Hohman DW, Noghrehkar D, Ratnayake S. 2008. Lymphangioleiomyomatosis: A review. Eur J Intern Med 19: 319-324.

Hong YK, Detmar M. 2003. Prox1, master regulator of the lymphatic vasculature phenotype. Cell Tissue Res 314: 85-92.

Hong YK, Harvey N, Noh YH, Schacht V, Hirakawa S, Detmar M, Oliver G. 2002. Proxl is a master control gene in the program specifying lymphatic endothelial cell fate. Dev Dyn 225: 351-357.

Hong YK, Foreman K, Shin JW, Hirakawa S, Curry CL, Sage DR, Libermann T, Dezube BJ, Fingeroth JD, Detmar M 2004. Lymphatic reprogramming of blood vascular endothelium by Kaposi sarcoma-associated herpesvirus. Nat Genet 36: 683-685.

Honnor A. 2008. Classification, aetiology and nursing management of lymphoedema. Br J Nurs 17: 576-586.

Hoover RE, Kelley JS. 1971. Distichiasis and lymphedema: A hereditary syndrome with possible multiple defects. A report of a family. Trans Am Ophthalmol Soc 69: 293-306.

Hosking B, François M, Wilhelm D, Orsenigo F, Caprini A Svingen T, Tutt D, Davidson T, Browne C, Dejana E, et al 2009. Sox7 and Sox17 are strain-specific modifiers of the lymphangiogenic defects caused by Sox 18 dysfunction in mice. Development 136: 2385-2391.

Huggenberger R, Ullmann S, Proulx ST, Pytowski B, Alitalo K, Detmar M. 2010. Stimulation of lymphangiogenesis via VEGFR-3 inhibits chronic skin inflammation. J Exp Med 207: 2255-2269.

Huggenberger R, Siddiqui SS, Brander D, Ullmann S, Zimmermann K, Antsiferova M, Werner S, Alitalo K, Detmar M. 2011. An important role of lymphatic vessel activation in limiting acute inflammation. Blood 117: 4667-4678.

Irrthum A, Karkkainen MJ, Devriendt K, Alitalo K, Vikkula M. 2000. Congenital hereditary lymphedema caused by a mutation that inactivates VEGFR3 tyrosine kinase. Am J Hum Genet 67: 295-301.

Irrthum A, Devriendt K, Chitayat D, Matthijs G, Glade C, Steijlen PM, Fryns JP, Van Steensel MA, Vikkula M. 2003. Mutations in the transcription factor gene SOX18 underlie recessive and dominant forms of hypotrichosis-lymphedema-telangiectasia. Am J Hum Genet 72: $1470-1478$.

Jackson DG. 2003. The lymphatics revisited: New perspectives from the hyaluronan receptor LYVE-1. Trends Cardiovasc Med 13: 1-7.

Jackson DG. 2004. Biology of the lymphatic marker LYVE-1 and applications in research into lymphatic trafficking and lymphangiogenesis. APMIS 112: 526-538.

Jackson DG. 2009. Immunological functions of hyaluronan and its receptors in the lymphatics. Immunol Rev 230: 216-231.

Jeltsch M, Kaipainen A, Joukov V, Meng X, Lakso M, Rauvala $H$, Swartz M, Fukumura D, Jain RK, Alitalo K. 1997. Hyperplasia of lymphatic vessels in VEGF-C transgenic mice. Science 276: 1423-1425.

Jeon BH, Jang C, Han J, Kataru RP, Piao L, Jung K, Cha HJ, Schwendener RA, Jang KY, Kim KS, et al. 2008. Profound but dysfunctional lymphangiogenesis via vascular endothelial growth factor ligands from $\mathrm{CD}_{11} \mathrm{~b}^{+}$macrophages in advanced ovarian cancer. Cancer Res 68: 1100-1109.

Jester HG. 1977. Lymphedema-distichiasis. A rare hereditary syndrome. Hum Genet 39: 113-116.

Johnson NC, Dillard ME, Baluk P, McDonald DM, Harvey NL, Frase SL, Oliver G. 2008. Lymphatic endothelial cell identity is reversible and its maintenance requires Prox1 activity. Genes Dev 22: 3282-3291.

Kaipainen A, Korhonen J, Mustonen T, van Hinsbergh VW, Fang GH, Dumont D, Breitman M, Alitalo K. 1995. Expression of the fms-like tyrosine kinase 4 gene becomes restricted to lymphatic endothelium during development. Proc Natl Acad Sci 92: 3566-3570.

Kang S, Lee SP, Kim KE, Kim HZ, Memet S, Koh GY. 2009. Toll-like receptor 4 in lymphatic endothelial cells contributes to LPS-induced lymphangiogenesis by chemotactic recruitment of macrophages. Blood 113: 2605-2613.

Kang J, Yoo J, Lee S, Tang W, Aguilar B, Ramu S, Choi I, Otu HH, Shin JW, Dotto GP, et al. 2010. An exquisite crosscontrol mechanism among endothelial cell fate regulators directs the plasticity and heterogeneity of lymphatic endothelial cells. Blood 116: 140-150.

Kaposi M. 1872. Idiopathisches multiples Pigmentsarcom der Haut. Arch Dermatol Syphillis 4: 265-273.

Karalay O, Doberauer K, Vadodaria KC, Knobloch M, Berti L, Miquelajauregui A, Schwark M, Jagasia R, Taketo MM, Tarabykin V, et al. 2011. Prospero-related homeobox 1 gene (Prox1) is regulated by canonical Wnt signaling and has a stage-specific role in adult hippocampal neurogenesis. Proc Natl Acad Sci 108: 5807-5812.

Karkkainen MJ, Ferrell RE, Lawrence EC, Kimak MA, Levinson KL, McTigue MA, Alitalo K, Finegold DN. 2000. Missense mutations interfere with VEGFR-3 signalling in primary lymphoedema. Nat Genet 25: 153-159.

Karkkainen MJ, Saaristo A, Jussila L, Karila KA, Lawrence EC, Pajusola K, Bueler H, Eichmann A, Kauppinen R, Kettunen MI, et al. 2001. A model for gene therapy of 
human hereditary lymphedema. Proc Natl Acad Sci 98: 12677-12682.

Karkkainen MJ, Makinen T, Alitalo K. 2002. Lymphatic endothelium: A new frontier of metastasis research. Nat Cell Biol 4: E2-E5.

Karkkainen MJ, Haiko P, Sainio K, Partanen J, Taipale J, Petrova TV, Jeltsch M, Jackson DG, Talikka M, Rauvala $\mathrm{H}$, et al. 2004. Vascular endothelial growth factor $\mathrm{C}$ is required for sprouting of the first lymphatic vessels from embryonic veins. Nat Immunol 5: 74-80.

Karpanen T, Alitalo K. 2008. Molecular biology and pathology of lymphangiogenesis. Annu Rev Pathol 3: 367-397.

Kataru RP, Jung K, Jang C, Yang H, Schwendener RA, Baik JE, Han SH, Alitalo K, Koh GY. 2009. Critical role of $\mathrm{CD} 11 \mathrm{~b}+$ macrophages and VEGF in inflammatory lymphangiogenesis, antigen clearance, and inflammation resolution. Blood 113: 5650-5659.

Kataru RP, Kim H, Jang C, Choi DK, Koh BI, Kim M, Gollamudi S, Kim YK, Lee SH, Koh GY. 2011. T lymphocytes negatively regulate lymph node lymphatic vessel formation. Immunity 34: 96-107.

Kato Y, Fujita N, Kunita A, Sato S, Kaneko M, Osawa M, Tsuruo T. 2003. Molecular identification of Aggrus/ $\mathrm{T} 1 \alpha$ as a platelet aggregation-inducing factor expressed in colorectal tumors. J Biol Chem 278: 51599-51605.

Kato Y, Kaneko MK, Kunita A, Ito H, Kameyama A, Ogasawara S, Matsuura N, Hasegawa Y, Suzuki-Inoue K, Inoue O, et al. 2008. Molecular analysis of the pathophysiological binding of the platelet aggregation-inducing factor podoplanin to the C-type lectin-like receptor CLEC-2. Cancer Sci 99: 54-61.

Kazenwadel J, Michael MZ, Harvey NL. 2010. Proxl expression is negatively regulated by miR-181 in endothelial cells. Blood 116: 2395-2401.

Kerjaschki D, Huttary N, Raab I, Regele H, Bojarski-Nagy K, Bartel G, Krober SM, Greinix H, Rosenmaier A Karlhofer F, et al. 2006. Lymphatic endothelial progenitor cells contribute to de novo lymphangiogenesis in human renal transplants. Nat Med 12: 230-234.

Kiel KD, Rademacker AW. 1996. Early-stage breast cancer: Arm edema after wide excision and breast irradiation. Radiology 198: 279-283.

Kim KE, Koh YJ, Jeon BH, Jang C, Han J, Kataru RP, Schwendener RA, Kim JM, Koh GY. 2009. Role of $\mathrm{CD} 11 \mathrm{~b}+$ macrophages in intraperitoneal lipopolysaccharide-induced aberrant lymphangiogenesis and lymphatic function in the diaphragm. Am J Pathol 175: $1733-1745$.

Kirjavainen A, Sulg M, Heyd F, Alitalo K, Yla-Herttuala S, Moroy T, Petrova TV, Pirvola U. 2008. Proxl interacts with Atoh1 and Gfil, and regulates cellular differentiation in the inner ear sensory epithelia. Dev Biol 322: $33-45$.

Kriederman BM, Myloyde TL, Witte MH, Dagenais SL, Witte CL, Rennels M, Bernas MJ, Lynch MT, Erickson RP, Caulder MS, et al. 2003. FOXC2 haploinsufficient mice are a model for human autosomal dominant lymphedema-distichiasis syndrome. Hum Mol Genet 12: $1179-1185$.

Kriehuber E, Breiteneder-Geleff S, Groeger M, Soleiman A, Schoppmann SF, Stingl G, Kerjaschki D, Maurer D. 2001 Isolation and characterization of dermal lymphatic and blood endothelial cells reveal stable and functionally specialized cell lineages. J Exp Med 194: 797-808.

Kristof AS. 2010. mTOR signaling in lymphangioleiomyomatosis. Lymphat Res Biol 8: 33-42.

Kume T. 2009. The cooperative roles of Foxc1 and Foxc2 in cardiovascular development. Adv Exp Med Biol 665: $63-77$.

Kwiatkowski DJ. 2010. Animal models of lymphangioleiomyomatosis (LAM) and tuberous sclerosis complex (TSC). Lymphat Res Biol 8: 51-57.

Laerm A, Helmbold P, Goldberg M, Dammann R, Holzhausen HJ, Ballhausen WG. 2007. Prospero-related homeobox 1 (PROX1) is frequently inactivated by genomic deletions and epigenetic silencing in carcinomas of the bilary system. J Hepatol 46: 89-97.

Lahteenvuo M, Honkonen K, Tervala T, Tammela T, Suominen E, Lahteenvuo J, Kholova I, Alitalo K, Yla-Herttuala S, Saaristo A. 2011. Growth factor therapy and autologous lymph node transfer in lymphedema. Circulation 123: 613-620.

Lanner F, Sohl M, Farnebo F. 2007. Functional arterial and venous fate is determined by graded VEGF signaling and notch status during embryonic stem cell differentiation. Arterioscler Thromb Vasc Biol 27: 487-493.

Lawson ND, Scheer N, Pham VN, Kim CH, Chitnis AB, Campos-Ortega JA, Weinstein BM. 2001. Notch signaling is required for arterial-venous differentiation during embryonic vascular development. Development 128: $3675-3683$.

Lawson ND, Vogel AM, Weinstein BM. 2002. sonic hedgehog and vascular endothelial growth factor act upstream of the Notch pathway during arterial endothelial differentiation. Dev Cell 3: 127-136.

Leak LV, Burke JF. 1966. Fine structure of the lymphatic capillary and the adjoining connective tissue area. Am J Anat 118: 785-809.

Leak LV, Burke JF. 1968. Ultrastructural studies on the lymphatic anchoring filaments. J Cell Biol 36: 129-149.

Lee S, Kang J, Yoo J, Ganesan SK, Cook SC, Aguilar B, Ramu S, Lee J, Hong YK. 2009. Proxl physically and functionally interacts with COUP-TFII to specify lymphatic endothelial cell fate. Blood 113: 1856-1859.

Lee JY, Park C, Cho YP, Lee E, Kim H, Kim P, Yun SH, Yoon YS. 2010a. Podoplanin-expressing cells derived from bone marrow play a crucial role in postnatal lymphatic neovascularization. Circulation 122: 1413-1425.

Lee S, Choi I, Hong YK. 2010b. Heterogeneity and plasticity of lymphatic endothelial cells. Semin Thromb Hemost 36: $352-361$.

Leeds SE. 1977. Three centuries of history of the lymphatic system. Surg Gynecol Obstet 144: 927-934.

Li L, Vaessin H. 2000. Pan-neural Prospero terminates cell proliferation during Drosophila neurogenesis. Genes Dev 14: $147-151$.

Lin FJ, Tsai MJ, Tsai SY. 2007. Artery and vein formation: A tug of war between different forces. EMBO Rep 8: 920-924.

Lin FJ, Chen X, Qin J, Hong YK, Tsai MJ, Tsai SY. 2010. Direct transcriptional regulation of neuropilin-2 by COUP-TFII modulates multiple steps in murine lymphatic vessel development. J Clin Invest 120: 1694-1707. 
I. Choi et al.

Lord RS. 1968. The white veins: Conceptual difficulties in the history of the lymphatics. Med Hist 12: 174-184.

Lund AW, Swartz MA. 2010. Role of lymphatic vessels in tumor immunity: Passive conduits or active participants? J Mammary Gland Biol Neoplasia 15: 341-352.

Luong MX, Tam J, Lin Q, Hagendoorn J, Moore KJ, Padera TP, Seed B, Fukumura D, Kucherlapati R, Jain RK. 2009. Lack of lymphatic vessel phenotype in LYVE-1/CD44 double knockout mice. J Cell Physiol 219: 430-437.

Majeski J. 1986. Lymphedema tarda. Cutis 38: 105-107.

Makinen T, Adams RH, Bailey J, Lu Q, Ziemiecki A, Alitalo $\mathrm{K}$, Klein R, Wilkinson GA. 2005. PDZ interaction site in ephrinB2 is required for the remodeling of lymphatic vasculature. Genes Dev 19: 397-410.

Medina-Martinez O, Brownell I, Amaya-Manzanares F, Hu Q, Behringer RR, Jamrich M. 2005. Severe defects in proliferation and differentiation of lens cells in Foxe3 null mice. Mol Cell Biol 25: 8854-8863.

Miller AJ, Bruna J, Beninson J. 1999. A universally applicable clinical classification of lymphedema. Angiology 50: 189-192.

Milroy WF. 1892. An undescribed variety of hereditary oedema. NY Med J 56: 505-508.

Milroy WF. 1928. Chronic hereditary edema: Milroy's disease. JAMA 91: 1172-1174.

Miteva DO, Rutkowski JM, Dixon JB, Kilarski W, Shields JD, Swartz MA. 2010. Transmural flow modulates cell and fluid transport functions of lymphatic endothelium. Circ Res 106: 920-931.

Miura H, Kusakabe Y, Kato H, Miura-Ohnuma J, Tagami M, Ninomiya Y, Hino A. 2003. Co-expression pattern of Shh with Prox1 and that of Nkx2.2 with Mash1 in mouse taste bud. Gene Expr Patterns 3: 427-430.

Mortimer PS. 1998. The pathophysiology of lymphedema. Cancer 83: 2798-2802.

Muthuchamy M, Zawieja D. 2008. Molecular regulation of lymphatic contractility. Ann NY Acad Sci 1131: 89-99.

Nakamura Y, Yasuoka H, Tsujimoto M, Yang Q, Imabun S, Nakahara M, Nakao K, Nakamura M, Mori I, Kakudo K. 2003. Flt-4-positive vessel density correlates with vascular endothelial growth factor-D expression, nodal status, and prognosis in breast cancer. Clinical Cancer Res 9: 5313-5317.

Neufeld G, Cohen T, Shraga N, Lange T, Kessler O, Herzog Y. 2002. The neuropilins: Multifunctional semaphorin and VEGF receptors that modulate axon guidance and angiogenesis. Trends Cardiovasc Med 12: 13-19.

Niessen K, Zhang G, Ridgway JB, Chen H, Kolumam G, Siebel CW, Yan M. 2011. The Notch1-Dll4 signaling pathway regulates mouse postnatal lymphatic development. Blood 118: 1989-1997.

Noguera-Troise I, Daly C, Papadopoulos NJ, Coetzee S, Boland P, Gale NW, Lin HC, Yancopoulos GD, Thurston G. 2006. Blockade of Dll4 inhibits tumour growth by promoting non-productive angiogenesis. Nature 444: $1032-1037$.

Norrmen C, Ivanov KI, Cheng J, Zangger N, Delorenzi M, Jaquet M, Miura N, Puolakkainen P, Horsley V, Hu J, et al. 2009. FOXC2 controls formation and maturation of lymphatic collecting vessels through cooperation with NFATc1. J Cell Biol 185: 439-457.
Norrmen C, Tammela T, Petrova TV, Alitalo K. 2011. Biological basis of therapeutic lymphangiogenesis. Circulation 123: 1335-1351.

Northup KA, Witte MH, Witte CL. 2003. Syndromic classification of hereditary lymphedema. Lymphology 36: $162-189$.

Nose K, Saito H, Kuroki T. 1990. Isolation of a gene sequence induced later by tumor-promoting $12-\mathrm{O}$-tetradecanoylphorbol-13-acetate in mouse osteoblastic cells (MC3T3-E1) and expressed constitutively in rastransformed cells. Cell Growth Differ 1: 511-518.

Nougues J, Reyne Y, Barenton B, Chery T, Garandel V, Soriano J. 1993. Differentiation of adipocyte precursors in a serum-free medium is influenced by glucocorticoids and endogenously produced insulin-like growth factor-I. Int J Obes Relat Metab Disord 17: 159-167.

Ohara I, Taneichi N. 1973. Lymphaticovenous anastomosis in a case with primary lymphedema tarda. Angiology 24: $668-674$.

Oka M, Iwata C, Suzuki HI, Kiyono K, Morishita Y, Watabe T, Komuro A, Kano MR, Miyazono K. 2008. Inhibition of endogenous TGF- $\beta$ signaling enhances lymphangiogenesis. Blood 111: 4571-4579.

Oliver G. 2004. Lymphatic vasculature development. Nat Rev Immunol 4: 35-45.

Oliver G, Detmar M. 2002. The rediscovery of the lymphatic system: Old and new insights into the development and biological function of the lymphatic vasculature. Genes Dev 16: 773-783.

Oliver G, Sosa-Pineda B, Geisendorf S, Spana EP, Doe CQ, Gruss P. 1993. Prox 1, a prospero-related homeobox gene expressed during mouse development. Mech Dev 44: 3-16.

Ozaslan C, Kuru B. 2004. Lymphedema after treatment of breast cancer. Am J Surg 187: 69-72.

Pan MR, Chang TM, Chang HC, Su JL, Wang HW, Hung WC. 2009. Sumoylation of Prox1 controls its ability to induce VEGFR3 expression and lymphatic phenotypes in endothelial cells. J Cell Sci 122: 3358-3364.

Partanen TA, Alitalo K, Miettinen M. 1999. Lack of lymphatic vascular specificity of vascular endothelial growth factor receptor 3 in 185 vascular tumors. Cancer 86: 2406-2412.

Pedrioli DM, Karpanen T, Dabouras V, Jurisic G, van de Hoek G, Shin JW, Marino D, Kalin RE, Leidel S, Cinelli P, et al. 2010. miR-31 functions as a negative regulator of lymphatic vascular lineage-specific differentiation in vitro and vascular development in vivo. Mol Cell Biol 30: 3620-3634.

Petrova TV, Makinen T, Makela TP, Saarela J, Virtanen I, Ferrell RE, Finegold DN, Kerjaschki D, Yla-Herttuala S, Alitalo K. 2002. Lymphatic endothelial reprogramming of vascular endothelial cells by the Prox-1 homeobox transcription factor. EMBO J 21: 4593-4599.

Petrova TV, Karpanen T, Norrmen C, Mellor R, Tamakoshi T, Finegold D, Ferrell R, Kerjaschki D, Mortimer P, YlaHerttuala S, et al. 2004. Defective valves and abnormal mural cell recruitment underlie lymphatic vascular failure in lymphedema distichiasis. Nat Med 10: 974-981.

Petrova TV, Nykanen A, Norrmen C, Ivanov KI, Andersson LC, Haglund C, Puolakkainen P, Wempe F, von Melchner 
H, Gradwohl G, et al. 2008. Transcription factor PROX1 induces colon cancer progression by promoting the transition from benign to highly dysplastic phenotype. Cancer Cell 13: 407-419.

Pezner RD, Patterson MP, Hill LR, Lipsett JA, Desai KR, Vora N, Wong JY, Luk KH. 1986. Arm lymphedema in patients treated conservatively for breast cancer: Relationship to patient age and axillary node dissection technique. Int $J$ Radiat Oncol Biol Phys 12: 2079-2083.

Pfarr KM, Debrah AY, Specht S, Hoerauf A. 2009. Filariasis and lymphoedema. Parasite Immunol 31: 664-672.

Phng LK, Gerhardt H. 2009. Angiogenesis: A team effort coordinated by notch. Dev Cell 16: 196-208.

Podgrabinska S, Braun P, Velasco P, Kloos B, Pepper MS, Skobe M. 2002. Molecular characterization of lymphatic endothelial cells. Proc Natl Acad Sci 99: 16069-16074.

Podgrabinska S, Kamalu O, Mayer L, Shimaoka M, Snoeck H, Randolph GJ, Skobe M. 2009. Inflamed lymphatic endothelium suppresses dendritic cell maturation and function via Mac-1/ICAM-1-dependent mechanism. $J$ Immunol 183: 1767-1779.

Ramirez MI, Millien G, Hinds A, Cao Y, Seldin DC, Williams MC. 2003. T1 $\alpha$, a lung type I cell differentiation gene, is required for normal lung cell proliferation and alveolus formation at birth. Dev Biol 256: 61-72.

Randolph GJ. 2001. Dendritic cell migration to lymph nodes: Cytokines, chemokines, and lipid mediators. Semin Immunol 13: 267-274.

Ridgway J, Zhang G, Wu Y, Stawicki S, Liang WC, Chanthery Y, Kowalski J, Watts RJ, Callahan C, Kasman I, et al. 2006. Inhibition of Dll4 signalling inhibits tumour growth by deregulating angiogenesis. Nature 444: 1083-1087.

Risebro CA, Searles RG, Melville AA, Ehler E, Jina N, Shah S, Pallas J, Hubank M, Dillard M, Harvey NL, et al. 2009. Prox1 maintains muscle structure and growth in the developing heart. Development 136: 495-505.

Robinow M, Johnson GF, Verhagen AD. 1970. Distichiasislymphedema. A hereditary syndrome of multiple congenital defects. Am J Dis Child 119: 343-347.

Rockson SG. 1998. Precipitating factors in lymphedema: Myths and realities. Cancer 83: 2814-2816.

Rockson SG. 2000. Lymphedema. Curr Treat Options Cardiovasc Med 2: 237-242.

Rockson SG. 2009. Lymphedema, at the forefront. Lymphat Res Biol 7: 1-2.

Rosen ED. 2002. The molecular control of adipogenesis, with special reference to lymphatic pathology. Ann N Y Acad Sci 979: 188-196.

Royston D, Jackson DG. 2009. Mechanisms of lymphatic metastasis in human colorectal adenocarcinoma. J Pathol 217: 608-619.

Rusznyak I, Foeldi M, Szabo G. 1967. Lymphatics and lymph circulation. Pergamon Press, Oxford.

Saaristo A, Tammela T, Timonen J, Yla-Herttuala S, Tukiainen E, Asko-Seljavaara S, Alitalo K. 2004. Vascular endothelial growth factor-C gene therapy restores lymphatic flow across incision wounds. FASEB J 18: 1707-1709.

Sabin FR. 1902. On the origin of the lymphatic system from the veins and the development of the lymph hearts and thoracic duct in the pig. Am J Anat 1: 367-391.
Sabin FR. 1904. On the development of the superficial lymphatics in the skin of the pig. Am J Anat 3: 183-195.

Saeki H, Moore AM, Brown MJ, Hwang ST. 1999. Cutting edge: Secondary lymphoid-tissue chemokine (SLC) and CC chemokine receptor 7 (CCR7) participate in the emigration pathway of mature dendritic cells from the skin to regional lymph nodes. J Immunol 162: 2472-2475.

Schacht V, Ramirez MI, Hong YK, Hirakawa S, Feng D, Harvey N, Williams M, Dvorak AM, Dvorak HF, Oliver G, et al. 2003. T1 $\alpha /$ podoplanin deficiency disrupts normal lymphatic vasculature formation and causes lymphedema. EMBO J 22: 3546-3556.

Segal J, Turner AF. 1976. Lymphedema tarda. JAMA 235: 1996-1997.

Seo S, Fujita H, Nakano A, Kang M, Duarte A, Kume T. 2006. The forkhead transcription factors, Foxc1 and Foxc2, are required for arterial specification and lymphatic sprouting during vascular development. Dev Biol 294: 458-470.

Seyama K, Kumasaka T, Kurihara M, Mitani K, Sato T. 2010. Lymphangioleiomyomatosis: A disease involving the lymphatic system. Lymphat Res Biol 8: 21-31.

Shawber CJ, Funahashi Y, Francisco E, Vorontchikhina M, Kitamura Y, Stowell SA, Borisenko V, Feirt N, Podgrabinska S, Shiraishi K, et al. 2007. Notch alters VEGF responsiveness in human and murine endothelial cells by direct regulation of VEGFR-3 expression. J Clin Invest 117: 3369-3382.

Shenoy RK. 2006. Lymphatic filariasis in children. J Commun Dis 38: 118-123.

Siekmann AF, Lawson ND. 2007. Notch signalling limits angiogenic cell behaviour in developing zebrafish arteries. Nature 445: 781-784.

Sivakumar R, Sharma-Walia N, Raghu H, Veettil MV, Sadagopan S, Bottero V, Varga L, Levine R, Chandran B. 2008. Kaposi's sarcoma-associated herpesvirus induces sustained levels of vascular endothelial growth factors A and $\mathrm{C}$ early during in vitro infection of human microvascular dermal endothelial cells: Biological implications. J Virol 82: 1759-1776.

Skobe M, Detmar M. 2000. Structure, function, and molecular control of the skin lymphatic system. J Investig Dermatol Symp Proc 5: 14-19.

Skobe M, Hawighorst T, Jackson DG, Prevo R, Janes L, Velasco P, Riccardi L, Alitalo K, Claffey K, Detmar M. 2001. Induction of tumor lymphangiogenesis by VEGF-C promotes breast cancer metastasis. Nat Med 7: 192-198.

Sosa-Pineda B, Wigle JT, Oliver G. 2000. Hepatocyte migration during liver development requires Prox1. Nat Genet 25: 254-255.

Srinivasan RS, Dillard ME, Lagutin OV, Lin FJ, Tsai S, Tsai MJ, Samokhvalov IM, Oliver G. 2007. Lineage tracing demonstrates the venous origin of the mammalian lymphatic vasculature. Genes Dev 21: 2422-2432.

Srinivasan RS, Geng X, Yang Y, Wang Y, Mukatira S, Studer M, Porto MP, Lagutin O, Oliver G. 2010. The nuclear hormone receptor Coup-TFII is required for the initiation and early maintenance of Proxl expression in lymphatic endothelial cells. Genes Dev 24: 696-707.

Stacker SA, Caesar C, Baldwin ME, Thornton GE, Williams RA, Prevo R, Jackson DG, Nishikawa S, Kubo H, Achen 
I. Choi et al.

MG. 2001. VEGF-D promotes the metastatic spread of tumor cells via the lymphatics. Nat Med 7: 186-191.

Steffensen KR, Holter E, Bavner A, Nilsson M, Pelto-Huikko M, Tomarev S, Treuter E. 2004. Functional conservation of interactions between a homeodomain cofactor and a mammalian FTZ-F1 homologue. EMBO Rep 5: 613-619.

Suzuki-Inoue K. 2011. Essential in vivo roles of the platelet activation receptor CLEC-2 in tumor metastasis, lymphangiogenesis, and thrombus formation. J Biochem 150: $127-132$.

Suzuki-Inoue K, Fuller GL, Garcia A, Eble JA, Pohlmann S, Inoue O, Gartner TK, Hughan SC, Pearce AC, Laing GD, et al. 2006. A novel Syk-dependent mechanism of platelet activation by the C-type lectin receptor CLEC-2. Blood 107: $542-549$.

Suzuki-Inoue K, Kato Y, Inoue O, Kaneko MK, Mishima K, Yatomi Y, Yamazaki Y, Narimatsu H, Ozaki Y. 2007. Involvement of the snake toxin receptor CLEC-2, in podoplanin-mediated platelet activation, by cancer cells. J Biol Chem 282: 25993-26001.

Suzuki-Inoue K, Inoue O, Ding G, Nishimura S, Hokamura K, Eto K, Kashiwagi H, Tomiyama Y, Yatomi Y, Umemura $\mathrm{K}$, et al. 2010. Essential in vivo roles of the C-type lectin receptor CLEC-2: Embryonic/neonatal lethality of CLEC-2-deficient mice by blood/lymphatic misconnections and impaired thrombus formation of CLEC-2deficient platelets. J Biol Chem 285: 24494-24507.

Swartz MA, Hubbell JA, Reddy ST. 2008. Lymphatic drainage function and its immunological implications: From dendritic cell homing to vaccine design. Semin Immunol 20: $147-156$.

Szuba A, Rockson SG. 1998. Lymphedema: Classification, diagnosis and therapy. Vasc Med 3: 145-156.

Szuba A, Skobe M, Karkkainen MJ, Shin WS, Beynet DP, Rockson NB, Dakhil N, Spilman S, Goris ML, Strauss HW, et al. 2002. Therapeutic lymphangiogenesis with human recombinant VEGF-C. FASEB J 16: 1985-1987.

Tammela T, Alitalo K. 2010. Lymphangiogenesis: Molecular mechanisms and future promise. Cell 140: 460-476.

Tammela T, Saaristo A, Holopainen T, Lyytikka J, Kotronen A, Pitkonen M, Abo-Ramadan U, Yla-Herttuala S, Petrova TV, Alitalo K. 2007. Therapeutic differentiation and maturation of lymphatic vessels after lymph node dissection and transplantation. Nat Med 13: 1458-1466.

Tomarev SI, Sundin O, Banerjee-Basu S, Duncan MK, Yang JM, Piatigorsky J. 1996. Chicken homeobox gene Prox 1 related to Drosophila prospero is expressed in the developing lens and retina. Dev Dyn 206: 354-367.

Tomarev SI, Zinovieva RD, Chang B, Hawes NL. 1998. Characterization of the mouse Proxl gene. Biochem Biophys Res Commun 248: 684-689.

Torii M, Matsuzaki F, Osumi N, Kaibuchi K, Nakamura S, Casarosa S, Guillemot F, Nakafuku M. 1999. Transcription factors Mash-1 and Prox-1 delineate early steps in differentiation of neural stem cells in the developing central nervous system. Development 126: 443-456.

Traboulsi EI, Al-Khayer K, Matsumoto M, Kimak MA, Crowe S, Wilson SE, Finegold DN, Ferrell RE, Meisler DM. 2002. Lymphedema-distichiasis syndrome and FOXC2 gene mutation. Am J Ophthalmol 134: 592-596.
Turner M, Mee PJ, Costello PS, Williams O, Price AA, Duddy LP, Furlong MT, Geahlen RL, Tybulewicz VL. 1995. Perinatal lethality and blocked B-cell development in mice lacking the tyrosine kinase Syk. Nature 378: 298-302.

Uhrin P, Zaujec J, Breuss JM, Olcaydu D, Chrenek P, Stockinger H, Fuertbauer E, Moser M, Haiko P, Fassler R, et al. 2010. Novel function for blood platelets and podoplanin in developmental separation of blood and lymphatic circulation. Blood 115: 3997-4005.

Vaessin H, Grell E, Wolff E, Bier E, Jan LY, Jan YN. 1991. Prospero is expressed in neuronal precursors and encodes a nuclear protein that is involved in the control of axonal outgrowth in Drosophila. Cell 67: 941-953.

Valtola R, Salven P, Heikkila P, Taipale J, Joensuu H, Rehn M, Pihlajaniemi T, weich H, deWaal R, Alitalo K. 1999. VEGFR-3 and its ligand VEGF-C are associated with angiogenesis in breast cancer. Am J Pathol 154: 13811390.

Vieras F, Boyd CM. 1976. Letter: Lymphedema tarda. JAMA 236: $1116-1117$.

Vigl B, Aebischer D, Nitschke M, Iolyeva M, Rothlin T, Antsiferova O, Halin C. 2011. Tissue inflammation modulates gene expression of lymphatic endothelial cells and dendritic cell migration in a stimulus-dependent manner. Blood 118: 205-215.

Wang D, Feng J, Wen R, Marine JC, Sangster MY, Parganas E, Hoffmeyer A, Jackson CW, Cleveland JL, Murray PJ, et al. 2000. Phospholipase $\mathrm{C} \gamma 2$ is essential in the functions of $B$ cell and several Fc receptors. Immunity 13: 25-35.

Wang HW, Trotter MW, Lagos D, Bourboulia D, Henderson S, Makinen T, Elliman S, Flanagan AM, Alitalo K, Boshoff C. 2004. Kaposi sarcoma herpesvirus-induced cellular reprogramming contributes to the lymphatic endothelial gene expression in Kaposi sarcoma. Nat Genet 36: 687-693.

Weinstein BM, Lawson ND. 2002. Arteries, veins, Notch, and VEGF. Cold Spring Harb Symp Quant Biol 67: 155162.

Wetterwald A, Hoffstetter W, Cecchini MG, Lanske B, Wagner C, Fleisch H, Atkinson M. 1996. Characterization and cloning of the E11 antigen, a marker expressed by rat osteoblasts and osteocytes. Bone 18: 125-132.

Wheeler ES, Chan V, Wassman R, Rimoin DL, Lesavoy MA. 1981. Familial lymphedema praecox: Meige's disease. Plast Reconstr Surg 67: 362-364.

Wick N, Haluza D, Gurnhofer E, Raab I, Kasimir MT, Prinz M, Steiner CW, Reinisch C, Howorka A, Giovanoli P, et al. 2008. Lymphatic precollectors contain a novel, specialized subpopulation of podoplanin low, CCL27-expressing lymphatic endothelial cells. Am J Pathol 173: 1202-1209.

Wigle JT, Oliver G. 1999. Proxl function is required for the development of the murine lymphatic system. Cell 98: 769-778.

Wigle JT, Chowdhury K, Gruss P, Oliver G. 1999. Proxl function is crucial for mouse lens-fibre elongation. Nat Genet 21: 318-322.

Wigle JT, Harvey N, Detmar M, Lagutina I, Grosveld G, Gunn MD, Jackson DG, Oliver G. 2002. An essential role for Proxl in the induction of the lymphatic endothelial cell phenotype. EMBO J 21: 1505-1513. 
Wiley HE, Gonzalez EB, Maki W, Wu MT, Hwang ST. 2001 Expression of CC chemokine receptor-7 and regional lymph node metastasis of B16 murine melanoma. $J$ Natl Cancer Inst 93: 1638-1643.

Wilting J, Papoutsi M, Othman-Hassan K, RodriguezNiedenfuhr M, Prols F, Tomarev SI, Eichmann A. 2001. Development of the avian lymphatic system. Microsc Res Tech 55: 81-91.

Wilting J, Tomarev SI, Christ B, Schweigerer L. 2003. Lymphangioblasts in embryonic lymphangiogenesis. Lymphat Res Biol 1: 33-40.

Wilting J, Aref Y, Huang R, Tomarev SI, Schweigerer L, Christ B, Valasek P, Papoutsi M. 2006. Dual origin of avian lymphatics. Dev Biol 292: 165-173.

Witmer AN, van Blijswijk BC, Dai J, Hofman P, Partanen TA, Vrensen GF, Schlingemann RO. 2001. VEGFR-3 in adult angiogenesis. J Pathol 195: 490-497.

Yamazaki T, Yoshimatsu Y, Morishita Y, Miyazono K, Watabe T. 2009. COUP-TFII regulates the functions of Prox1 in lymphatic endothelial cells through direct interaction. Genes Cells 14: 425-434.

Yaniv K, Isogai S, Castranova D, Dye L, Hitomi J, Weinstein BM. 2006. Live imaging of lymphatic development in the zebrafish. Nat Med 12: 711-716.

Yoo J, Kang J, Lee HN, Aguilar B, Kafka D, Lee S, Choi I, Lee J, Ramu S, Haas J, et al. 2010. Kaposin-B enhances
Lymphatics, the Other Circulatory System

the PROX1 mRNA stability during lymphatic reprogramming of vascular endothelial cells by Kaposi's sarcoma herpes virus. PLoS Pathog 6: e1001046.

Yoon YS, Murayama T, Gravereaux E, Tkebuchava T, Silver M, Curry C, Wecker A, Kirchmair R, Hu CS, Kearney $\mathrm{M}$, et al. 2003. VEGF-C gene therapy augments postnatal lymphangiogenesis and ameliorates secondary lymphedema. J Clin Invest 111: 717-725.

You LR, Lin FJ, Lee CT, DeMayo FJ, Tsai MJ, Tsai SY. 2005. Suppression of Notch signalling by the COUP-TFII transcription factor regulates vein identity. Nature 435: 98-104.

Yuan L, Moyon D, Pardanaud L, Breant C, Karkkainen MJ, Alitalo K, Eichmann A. 2002. Abnormal lymphatic vessel development in neuropilin 2 mutant mice. Development 129: $4797-4806$

Zheng W, Tammela T, Yamamoto M, Anisimov A, Holopainen T, Kaijalainen S, Karpanen T, Lehti K, Yla-Herttuala S, Alitalo K. 2011. Notch restricts lymphatic vessel sprouting induced by vascular endothelial growth factor. Blood 118: 1154-1162.

Zimmer G, Oeffner F, Von Messling V, Tschernig T, Groness HJ, Klenk HD, Herrler G. 1999. Cloning and characterization of gp36, a human mucin-type glycoprotein preferentially expressed in vascular endothelium. Biochem J 341: $277-284$ 


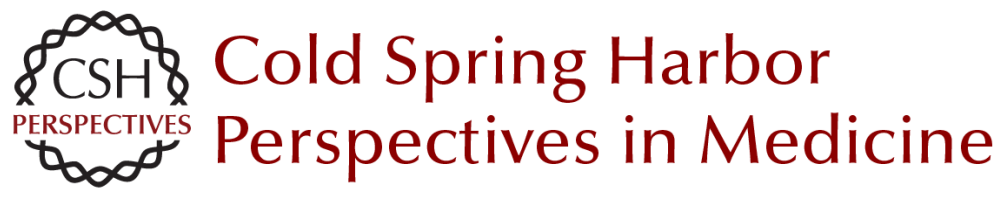

\title{
The New Era of the Lymphatic System: No Longer Secondary to the Blood Vascular System
}

\author{
Inho Choi, Sunju Lee and Young-Kwon Hong
}

Cold Spring Harb Perspect Med 2012; doi: 10.1101/cshperspect.a006445 originally published online January 25, 2012

\section{Subject Collection Angiogenesis}

Extracellular Matrix Regulation of Vascular Morphogenesis, Maturation, and Stabilization George E. Davis and Scott S. Kemp

Endothelial Cell-Pericyte Interactions in the

Pathogenesis of Cerebral Cavernous

Malformations (CCMs)

Wang Min and Jenny Huanjiao Zhou

Lymphatic Clearance and Pump Function Jerome W. Breslin

Platelets and (Lymph)angiogenesis Harvey G. Roweth and Elisabeth M. Battinelli

Modeling Brain Vasculature Immune Interactions In Vitro

Ruth Lyck, Hideaki Nishihara, Sidar Aydin, et al.

Human Endothelial Colony-Forming Cells Juan M. Melero-Martin

The Beauty and Complexity of Blood Vessel Patterning Victoria L. Bautch and Yoh-suke Mukouyama

Endothelialitis, Microischemia, and Intussusceptive Angiogenesis in COVID-19 Steven J. Mentzer, Maximilian Ackermann and Danny Jonigk
Regulation of the Blood-Brain Barrier in Health and Disease

Cara C. Rada, Kanako Yuki, Jie Ding, et al.

Targeting Angiogenesis via Resolution of Inflammation

Abigail G. Kelly and Dipak Panigrahy

Notch Signaling in the Vasculature: Angiogenesis and Angiocrine Functions

Sana S. Hasan and Andreas Fischer

Signal Transduction and Gene Regulation in the

Endothelium

Michel V. Levesque and Timothy Hla

Buttons and Zippers: Endothelial Junctions in

Lymphatic Vessels

Peter Baluk and Donald M. McDonald

Endothelial Cell Fate Determination: A Top Notch Job in Vascular Decision-Making

L.A. Naiche, Stephanie R. Villa and Jan K. Kitajewski

Leukocyte Trafficking in Lymphatic Vessels Aline Bauer, Hazal Tatliadim and Cornelia Halin

Lymphatic Tissue and Organ Engineering for In Vitro Modeling and In Vivo Regeneration Anna M. Kolarzyk, Gigi Wong and Esak Lee

For additional articles in this collection, see http://perspectivesinmedicine.cshlp.org/cgi/collection/ 